\title{
Modeling organic aerosol from the oxidation of $\alpha$-pinene in a Potential Aerosol Mass (PAM) chamber
}

\author{
S. Chen ${ }^{1}$, W. H. Brune ${ }^{1}$, A. T. Lambe ${ }^{2,3}$, P. Davidovits ${ }^{2}$, and T. B. Onasch ${ }^{2,3}$ \\ ${ }^{1}$ Department of Meteorology, Pennsylvania State University, University Park, PA, USA \\ ${ }^{2}$ Chemistry Department, Boston College, Chestnut Hill, MA, USA \\ ${ }^{3}$ Aerodyne Research Inc., Billerica, MA, USA
}

Correspondence to: S. Chen (suc185@psu.edu)

Received: 9 January 2013 - Published in Atmos. Chem. Phys. Discuss.: 25 January 2013

Revised: 22 April 2013 - Accepted: 23 April 2013 - Published: 15 May 2013

\begin{abstract}
A model has been developed to simulate the formation and evolution of secondary organic aerosol (SOA) and was tested against data produced in a Potential Aerosol Mass (PAM) flow reactor and a large environmental chamber. The model framework is based on the two-dimensional volatility basis set approach (2D-VBS), in which SOA oxidation products in the model are distributed on the 2-D space of effective saturation concentration $\left(C_{i}^{*}\right)$ and oxygen-to-carbon ratio $(\mathrm{O}: \mathrm{C})$. The modeled organic aerosol mass concentrations $\left(C_{\mathrm{OA}}\right)$ and $\mathrm{O}: \mathrm{C}$ agree with laboratory measurements within estimated uncertainties. However, while both measured and modeled $\mathrm{O}: \mathrm{C}$ increase with increasing $\mathrm{OH}$ exposure as expected, the increase of modeled $\mathrm{O}: \mathrm{C}$ is rapid at low $\mathrm{OH}$ exposure and then slows as $\mathrm{OH}$ exposure increases while the increase of measured $\mathrm{O}: \mathrm{C}$ is initially slow and then accelerates as $\mathrm{OH}$ exposure increases. A global sensitivity analysis indicates that modeled $C_{\mathrm{OA}}$ values are most sensitive to the assumed values for the number of $C_{i}^{*}$ bins, the heterogeneous $\mathrm{OH}$ reaction rate coefficient, and the yield of first-generation products. Modeled SOA O : $\mathrm{C}$ values are most sensitive to the assumed $\mathrm{O}: \mathrm{C}$ of first-generation oxidation products, the number of $C_{i}^{*}$ bins, the heterogeneous $\mathrm{OH}$ reaction rate coefficient, and the number of $\mathrm{O}: \mathrm{C}$ bins. All these sensitivities vary as a function of $\mathrm{OH}$ exposure. The sensitivity analysis indicates that the 2D-VBS model framework may require modifications to resolve discrepancies between modeled and measured $\mathrm{O}: \mathrm{C}$ as a function of $\mathrm{OH}$ exposure.
\end{abstract}

\section{Introduction}

Organic aerosols (OA) play an important role in environmental processes through their impact on climate and human health (EPA, 2012). A significant fraction of the OA is the secondary organic aerosols (SOA) (Yu et al., 2007), which are produced by the gas-to-particle conversion of semivolatile oxidation products of volatile organic compounds (VOCs). However, the formation and continued oxidation of SOA involve a great number of complex physical and chemical processes, of which a quantitative and predictive understanding remains a major research challenge (Hallquist et al., 2009).

Great effort has been made to simulate the formation of SOA through different modeling approaches. Following the absorptive partitioning theory of Pankow (1994), a partitioning coefficient of a given species, $K_{\mathrm{p}}$, was defined to describe the thermodynamic equilibrium of the species between gasphase and condensed-phase. With detailed gas-phase reaction mechanisms, the formation of SOA can be modeled in an explicit way while the gas-to-particle transfer reactions are defined for all semivolatile reaction products. Unfortunately, a full explicit mechanism of SOA precursor oxidation is currently not practical since it would contain an unmanageable number of chemical reactions and intermediate species (Aumont et al., 2005). Odum et al. (1996) developed a two-product model, which is simply parameterized by laboratory derived stoichiometric yields and partitioning coefficients for two surrogate compounds and hence cannot represent the complexity of the SOA system (Hallquist et al., 2009). 
Donahue et al. (2006) and Robinson et al. (2007) proposed the volatility basis set (VBS) model framework to model SOA with only a few model parameters by lumping the oxidation products according to their volatility. The VBS framework distributes all organic species into volatility bins with discrete values of effective saturation concentration $C_{i}^{*}$ (in $\mu \mathrm{g} \mathrm{m}^{-3}$ ), separated by factors of 10 . The stoichiometric yields for each bin $\left(\alpha_{i}\right)$ can be parameterized by fitting the data from chamber experiments for a selection of $C_{i}^{*}$ values (Stanier et al., 2008). In addition to volatility, other properties of organic material such as hygroscopicity, polarity, and carbon number evolve with photochemical processing. To characterize the atmospheric evolution of SOA, Jimenez et al. (2009) and Donahue et al. (2011) developed a 2D-VBS model framework by using oxygen-to-carbon atomic ratio $(\mathrm{O}: \mathrm{C})$ as the second dimension. Products of the oxidation of organic precursors are classified by both $C_{i}^{*}$ and $\mathrm{O}: \mathrm{C}$ and mapped onto the 2D-VBS space. Further chemical processing can then be viewed to proceed through two competing pathways: functionalization and fragmentation. Functionalization refers to a net addition of oxygen without change of carbon number by adding oxygenated functional groups to a reactant, moving the products to lower volatility and higher oxidation states; fragmentation refers to a net loss of carbon due to carbon-carbon bond cleavage (Kroll et al., 2011).

An advantage of the VBS model is its treatment of both gas-phase and particle-phase organic compounds into products that are grouped into bins with common chemical behavior. This model has been coupled with different chemistry models (Murphy et al., 2011, 2012b; Roldin et al., 2011) and was found to be a good approximation of ambient SOA formation and chemical aging processes. The $2 \mathrm{D}-\mathrm{VBS}$ has been shown to provide at least a partial solution to representing the aging mechanism of $\alpha$-pinene SOA (Donahue et al., 2012a). Recently it was also used to model SOA mass yields from six linear oxygenated precursors (Chacon-Madrid et al., 2012) and showed reasonable agreement with smog-chamber measurements. However, many model processes are parameterized to describe the kinetic evolution of SOA, the probability of functionalization and fragmentation, the distribution of the oxidation products in the 2-D space, and the configuration of aging processes. These parameterizations may influence the model results (e.g., Lane et al., 2008; Murphy et al., 2011; and Cappa and Wilson, 2012) and can be examined by testing the 2D-VBS model against more laboratory measurements and by exploring the model uncertainty with a sensitivity study, especially for atmospherically relevant SOA aging.

In the atmosphere, a typical residence time for a particle is $\sim 1$ week (Wagstrom and Pandis, 2009). Conventional smog-chamber techniques cannot reproduce this equivalent level of atmospheric oxidation in the laboratory (e.g., $\mathrm{Ng}$ et al., 2010). However, recent measurements suggest that it is possible to simulate atmospheric SOA oxidation in a small, highly reactive, flow-through chamber, such as the Potential
Aerosol Mass (PAM) chamber (Kang et al., 2007; Lambe et al., 2011, 2012; Bahreini et al., 2012). In the PAM chamber, SOA is formed and oxidized over integrated exposure times ranging from one day to more than a week of equivalent atmospheric oxidation. Thus the PAM chamber can produce atmospheric levels of oxidation that are not possible in conventional smog chambers. The PAM chamber therefore provides an opportunity to evaluate the 2D-VBS approach for the evolution of SOA over multiple generations of oxidation.

In this work, we focus on SOA produced from $\alpha$-pinene, which is the most highly emitted monoterpene (Guenther et al., 1995). As a result, laboratory $\alpha$-pinene SOA is commonly used as a surrogate for ambient biogenic SOA, which is thought to dominate the global SOA budget (Hallquist et al., 2009; Spracklen et al., 2011). The experimental measurements of $\alpha$-pinene SOA mass concentrations $\left(C_{\mathrm{OA}}\right)$ and $\mathrm{O}: \mathrm{C}$ in the PAM chamber are used to evaluate simulations from a recently developed 2D-VBS model, which is described herein. The model and PAM measurements are also compared to results from the Caltech environmental chamber $(\mathrm{Ng}$ et al., 2007, 2010; Lambe et al., 2011). Model uncertainties are examined by changing model parameters and the sensitivity of the modeled $C_{\mathrm{OA}}$ and $\mathrm{O}: \mathrm{C}$ to the model parameters are assessed with a global sensitivity analysis.

\section{Model and measurements}

\subsection{PAM chamber conditions}

A detailed description of the PAM chamber can be found in Lambe et al. (2011). Only a brief summary is presented here. The PAM chamber is a horizontal $13.1 \mathrm{~L}$ glass cylindrical chamber $(46 \mathrm{~cm}$ length $\times 22 \mathrm{~cm}$ diameter) with a surface-tovolume $(S A / V)$ ratio of $0.14 \mathrm{~cm}^{-1}$. To minimize wall interactions in the PAM, flow is sub-sampled from the center of the reactor while the flow near the walls is pumped out through a bypass. Four mercury lamps (BHK Inc.) with peak emission intensity at $\lambda=254 \mathrm{~nm}$ are mounted inside the chamber. Ozone $\left(\mathrm{O}_{3}\right)$ introduced in the PAM is photolyzed to produce excited oxygen $\left(\mathrm{O}\left({ }^{1} \mathrm{D}\right)\right)$, which then reacts with water vapor (relative humidity RH of 20-40\%) to produce $\mathrm{OH}$ radicals at levels ranging from $\sim 10^{8}$ to $\sim 10^{10} \mathrm{molec}^{-3}$. The $\mathrm{OH}$ exposure was varied by changing the UV light intensity and typically measured at $2.0 \times$ $10^{10}$ to $2.2 \times 10^{12} \mathrm{molec} \mathrm{cm}^{-3} \mathrm{~s}$, roughly corresponding to 0.2-17 days of atmospheric oxidation at an equivalent ambient $\mathrm{OH}$ concentration of $1.5 \times 10^{6} \mathrm{molec}^{-3}$ (Mao et al., 2009).

Thirteen different initial amounts of $\alpha$-pinene $(\triangle \mathrm{VOC}=$ $23-833 \mu \mathrm{g} \mathrm{m}^{-3}$ ) were introduced in the PAM chamber at room temperature $\left(20-25^{\circ} \mathrm{C}\right)$. One set of measurements was conducted with $\mathrm{O}_{3} \sim 8$ ppmv and RH of 20-25\%. The other set of measurements was conducted with $\mathrm{O}_{3} \sim 20$ ppmv and $\mathrm{RH}$ of $30-40 \%$. SOA was formed by the gas-phase oxidation 
of $\alpha$-pinene followed by homogeneous nucleation and condensational growth. Seed particles were not used. Particle number concentrations were measured with a TSI Scanning Mobility Particle Sizer (SMPS) and Aerodyne compact and high-resolution time-of-flight aerosol mass spectrometers (AMS) (Drewnick et al., 2005; DeCarlo et al., 2006). The averages of SOA mass concentrations $\left(C_{\mathrm{OA}}\right)$ measured by the SMPS and AMS were used. The uncertainty in $C_{\mathrm{OA}}$ was estimated to be $\pm 25 \%$ ( $1 \sigma$ confidence level), which combines the uncertainties in both SMPS and AMS measurements, the AMS ionization efficiency calibration, and calculated effective density. The aerosol $\mathrm{O}: \mathrm{C}$ ratios were determined by elemental analysis (Aiken et al., 2008) with an uncertainty of $\pm 15 \%$ ( $1 \sigma$ confidence level) (Massoli et al., 2010). The measured relationship between $C_{\mathrm{OA}}$ or $\mathrm{O}: \mathrm{C}$ and $\mathrm{OH}$ exposure were then compared to those from model simulations for the 13 different initial $\alpha$-pinene amounts.

\subsection{SOA model based on 2D-VBS}

The SOA model was developed based on the 2D-VBS model coupled with a series of reactions that take place in the PAM chamber. The base-case 2D-VBS scheme used in this work classified the organic products with $C_{i}^{*}$ at $298 \mathrm{~K}$ of $10^{-5}$ to $10^{4} \mu \mathrm{g} \mathrm{m}^{-3}$, separated by factors of 10 (i.e., 10 bins of volatility, $n_{x}=10$ ). The $\mathrm{O}: \mathrm{C}$ of the organic products ranges from 0.1 to 1.2 while linearly separated by 0.1 (i.e., 12 bins of oxygenation, $n_{y}=12$ ), consistent with the previous studies (e.g., Murphy et al., 2011, 2012b). Therefore 120 grouped organic species were defined in the 2-D space.

The inorganic reactions associated with $\mathrm{OH}, \mathrm{O}_{3}$, water vapor, and the intermediates and their rate coefficients were adapted from Sander et al. (2011). The actinic flux at $\lambda=254 \mathrm{~nm}$ (Flux254) emitted by the PAM chamber lamps was assumed to be $(2-5) \times 10^{14}$ photons $\mathrm{cm}^{-2} \mathrm{~s}^{-1}$. The exact modeled Flux254 is not important for this study because, while $\mathrm{OH}$ exposure depends on Flux254, $C_{\mathrm{OA}}$ and $\mathrm{O}: \mathrm{C}$ depend almost exclusively on $\mathrm{OH}$ exposure, which is used as the independent variable in the following analyses. The photolysis frequencies of $\mathrm{O}_{3}, \mathrm{HO}_{2}$, and $\mathrm{H}_{2} \mathrm{O}_{2}$ were approximated by the product of the actinic flux, quantum yields, and absorption cross sections based on Sander et al. (2011). The reaction rate coefficients of the oxidations of $\alpha$-pinene by $\mathrm{OH}$ and $\mathrm{O}_{3}$ were adapted from Atkinson et al. (2006). A forward finite-difference approach (e.g., Dzepina et al., 2009) was used in the model to calculate the accumulated products. For instance, the concentration variation of $\alpha$-pinene d[VOC] was approximated by

$$
\begin{aligned}
& \frac{\mathrm{d}[\mathrm{VOC}]}{\mathrm{d} t} \approx \frac{\Delta[\mathrm{VOC}]}{\Delta t}=\frac{[\mathrm{VOC}]_{t+1}-[\mathrm{VOC}]_{t}}{\Delta t} \\
& =-k_{\mathrm{VOC}+\mathrm{OH}}[\mathrm{VOC}]_{t}[\mathrm{OH}]_{t}-k_{\mathrm{VOC}+\mathrm{O}_{3}}[\mathrm{VOC}]_{t}\left[\mathrm{O}_{3}\right]_{t}
\end{aligned}
$$

with a sufficiently small time step $\mathrm{d} t$.

To simulate the formation of the products from the firstgeneration oxidation by $\mathrm{O}_{3}$, the stoichiometric yields $\alpha_{i}$ de-
Table 1. The initial O:C and mass yields $\alpha_{i}$ of VBS products from the oxidation of $\alpha$-pinene.

\begin{tabular}{llll}
\hline $\begin{array}{l}C_{i}^{*} \\
\left(\mu \mathrm{g} \mathrm{m}^{-3}\right)\end{array}$ & $\alpha_{i}$ & O:C & $\begin{array}{l}\text { Molecular Weight } \\
\left(\mathrm{g} \mathrm{mol}^{-1}\right)\end{array}$ \\
\hline $10^{0}$ & 0.024 & 0.4 & 200 \\
$10^{1}$ & 0.078 & 0.3 & 184 \\
$10^{2}$ & 0.060 & 0.45 & 150 \\
$10^{3}$ & 0.222 & 0.2 & 168 \\
$10^{4}$ & 0.770 & 0.45 & 150 \\
Reference & Pathak et al. (2007) & $\begin{array}{l}\text { Chan et al. (2009); } \\
\text { Lambe et al. (2011) }\end{array}$ & $\begin{array}{l}\text { Chan et al. (2009); } \\
\text { Pathak et al. (2007) }\end{array}$ \\
\hline
\end{tabular}

rived by Pathak et al. (2007) for low $\mathrm{NO}_{\mathrm{x}}$ with UV light and dry conditions (Table 1) were used for all experiments. The effect of experimental conditions (e.g., RH and UV intensity) on yields $\alpha_{i}$ was not accounted due to limited available data. $\mathrm{O}: \mathrm{C}$ and molecular weights of most of these initial products (Table 1) were taken from Chan et al. (2009) if available. Otherwise, the model used $\mathrm{O}: \mathrm{C}$ of 0.45 (as reported in Lambe et al., 2011 for $\alpha$-pinene SOA at low $\mathrm{OH}$ exposure in the PAM chamber) and molecular weight of $150 \mathrm{~g} \mathrm{~mol}^{-1}$ (as estimated in Pathak et al., 2007). For OH oxidation, the model assumes that the products are the same as those from $\mathrm{O}_{3}$ oxidation of $\alpha$-pinene. The model also assumes instantaneous absorptive equilibrium with a gas-to-particle partitioning so that the mass fraction in the particle phase in each volatility bin (Donahue et al., 2006) can be defined by a partitioning coefficient $\xi_{i}$ for species $i$ with an effective saturation concentration $C_{i}^{*}$ :

$\xi_{i}=\left(1+\frac{C_{i}^{*}}{C_{\mathrm{OA}}}\right)^{-1} ; C_{\mathrm{OA}}=\sum_{i} C_{i}^{*} \xi_{i}$,

where $C_{\mathrm{OA}}$ is the total mass concentration of organic aerosol. The temperature dependence of $C_{i}^{*}$ is represented by the Clausius-Clapeyron equation (Donahue et al., 2006):

$C_{i}^{*}(T)=C_{i}^{*}\left(T_{\text {ref }}\right) \frac{T_{\text {ref }}}{T} \exp \left[\frac{\Delta H_{\mathrm{v}}}{R}\left(\frac{1}{T_{\text {ref }}}-\frac{1}{T}\right)\right]$,

where $T_{\text {ref }}$ is the reference temperature, $\Delta H_{\mathrm{v}}$ is the enthalpy of vaporization, and $R$ is the universal gas constant. A constant effective $\Delta H_{\mathrm{v}}$ of $30 \mathrm{~kJ} \mathrm{~mol}^{-1}$ was used in Pathak et al. (2007) for the VBS parameterization of the SOA yields from $\alpha$-pinene. However, Epstein et al. (2010) proposed a semiempirical correlation between $\Delta H_{\mathrm{v}}$ and $C_{i}^{*}$. Since $\Delta H_{\mathrm{v}}$ is an uncertain parameter, a constant temperature of $298 \mathrm{~K}$ was used in the base-case model. Because UV lamps in the PAM chamber lead to temperature increases (measured temperature $T_{\mathrm{obs}}=21-36{ }^{\circ} \mathrm{C}$ ) and hence less SOA formation, the modeled $C_{\mathrm{OA}}$ is hence compared with measurements corrected at -0.02 per degree $\mathrm{K}$ of temperature increase (Stanier et al., 2008) relative to $298 \mathrm{~K}$. This correction typically varies the $C_{\mathrm{OA}}$ measurements by $10-15 \%$. Additional model simulations were performed at measured temperature $T_{\mathrm{obs}}$ with either $\Delta H_{\mathrm{v}}=30 \mathrm{~kJ} \mathrm{~mol}^{-1}$ or the $C_{i}^{*}$-dependent $\Delta H_{\mathrm{v}}$ as in 
Table 2. The perturbation ranges and sampling probability distribution function (PDF) of model parameters of this SOA model.

\begin{tabular}{|c|c|c|c|c|c|}
\hline$\#$ & Parameter & Original value & Perturbation range & PDF & Reference \\
\hline 1 & Initial RH & $\begin{array}{l}20 \% \text { for lower RH cases; } \\
30 \% \text { for higher RH cases }\end{array}$ & $\begin{array}{l}20-25 \% \text { for lower RH } \\
\text { cases; } \\
30-40 \% \text { for higher RH } \\
\text { cases }\end{array}$ & uniform & This work \\
\hline 2 & $\begin{array}{l}\text { Number of } \\
C_{i}^{*} \text { bins } n_{x}\end{array}$ & 10 & $\begin{array}{l}8-12\left(10^{-5} \text { to } 10^{2} \text { or }\right. \\
\left.10^{6} \mathrm{\mu g} \mathrm{m}^{-3}\right)\end{array}$ & $\begin{array}{l}\text { uniform } \\
\text { integers }\end{array}$ & This work \\
\hline 3 & Number of $\mathrm{O}: \mathrm{C}$ bins $n_{y}$ & 12 & $10-14(0.1$ to 1.0 or 1.4$)$ & $\begin{array}{l}\text { uniform } \\
\text { integers }\end{array}$ & This work \\
\hline 4 & $\begin{array}{l}\text { Molecular weight of first- } \\
\text { generation products }\end{array}$ & See Table 1 & $150-200 \mathrm{~g} \mathrm{~mol}^{-1}$ & uniform & Chan et al. (2009) \\
\hline 5 & Homogeneous $k_{\mathrm{OH} \_h o m o}$ & $1 \times 10^{-11} \mathrm{~cm}^{3} \mathrm{~s}^{-1}$ & $(0.2-5) \times 10^{-11} \mathrm{~cm}^{3} \mathrm{~s}^{-1}$ & uniform & This work \\
\hline 6 & Homogeneous $k_{\mathrm{O}_{3}}$ & $1 \times 10^{-17} \mathrm{~cm}^{3} \mathrm{~s}^{-1}$ & $(0.2-5) \times 10^{-17} \mathrm{~cm}^{3} \mathrm{~s}^{-1}$ & uniform & This work \\
\hline 7 & Heterogeneous $k_{\mathrm{OH} \text { hetero }}$ & $1 \times 10^{-12} \mathrm{~cm}^{3} \mathrm{~s}^{-1}$ & $(0.2-5) \times 10^{-12} \mathrm{~cm}^{3} \mathrm{~s}^{-1}$ & uniform & This work \\
\hline 8 & $\begin{array}{l}\text { Initial } \mathrm{O}: \mathrm{C} \text { of first- } \\
\text { generation products }\end{array}$ & See Table 1 & $0.2-0.5$ & uniform & Chan et al. (2009) \\
\hline 9 & $\begin{array}{l}\text { Product yields of first- } \\
\text { generation products } \alpha_{i}\end{array}$ & See Table 1 & $\pm 20 \%$ & normal & This work \\
\hline 10 & $\begin{array}{l}\text { Carbon number of } \\
\text { grouped products } n_{\mathrm{C}}\end{array}$ & $\begin{array}{l}\text { Calculated from } \\
\text { Donahue et al. (2011) }\end{array}$ & $\pm 15 \%$ & uniform & This work \\
\hline 11 & $\begin{array}{l}f_{\mathrm{c}} \text { of fragmentation } \\
\text { coefficient } \beta=(\mathrm{O}: \mathrm{C})^{f_{\mathrm{c}}}\end{array}$ & $1 / 6$ & $0.1-0.5$ & uniform & This work \\
\hline 12 & Adding 10 probability $P_{10}$ & $29 \%$ & $0-0.5$ & uniform & This work \\
\hline 13 & $\begin{array}{l}\text { Adding 2Os probability } \\
P_{2 \mathrm{Os}}\end{array}$ & $49 \%$ & $0-0.5$ & uniform & This work \\
\hline- & $\begin{array}{l}\text { Adding 3Os probability } \\
P_{3 \mathrm{Os}}\end{array}$ & $22 \%$ & $1-P_{1 \mathrm{O}}-P_{2 \mathrm{Os}}$ & - & This work \\
\hline
\end{tabular}

Epstein et al. (2010) to explore the temperature sensitivity of the model (see Sect. 3.3.1). The model starts with a very small but nonzero value of initial $C_{\mathrm{OA}}\left(0.1 \mathrm{ng} \mathrm{m}^{-3}\right.$ as suggested in Kroll et al., 2007) to partition the organic products for the very beginning of the modeling.

All gas-phase products were assumed to react with $\mathrm{OH}$ and $\mathrm{O}_{3}$ at rate coefficients $k_{\mathrm{OH} \text { homo }}$ of $1 \times 10^{-11} \mathrm{~cm}^{3} \mathrm{molec}^{-1} \mathrm{~s}^{-1}$ and $k_{\mathrm{O}_{3}}$ of $1 \times$ $10^{-17} \mathrm{~cm}^{3}$ molec $^{-1} \mathrm{~s}^{-1}$, which have been used in previous studies (e.g., Murphy et al., 2011; Roldin et al., 2011; and Jathar et al., 2012). For particle-phase $\mathrm{OH}$ reactions, the model uses an effective rate coefficient $k_{\mathrm{OH} \text { hetero }}$ of 1 $\times 10^{-12} \mathrm{~cm}^{3} \mathrm{molec}^{-1} \mathrm{~s}^{-1}$, which is significantly slower than its gas-phase analogue (e.g., Jimenez et al., 2009; and Murphy et al., 2011). However, the model uses the same functionalization and fragmentation algorithm for products of heterogeneous reactions as it does for products of gas-phase reactions (e.g., Donahue et al., 2012a).

During the oxidation processes, both functionalization and fragmentation reactions affect the volatility and mass of SOA (Kroll et al., 2009; Chacon-Madrid and Donahue, 2011; Lambe et al., 2012). For the functionalization kernel, oxidation products were assumed to take-up 1, 2, or 3 oxygens (Table 2 ) and hence reduce their volatility by $1-7$ decades with separate probabilities (Jimenez et al., 2009; Roldin et al., 2011). Depending on the carbon number $n_{\mathrm{C}}$ of the parent product, which can be estimated by its $\mathrm{O}: \mathrm{C}$ and $C_{i}^{*}$ (Donahue et al., 2011), the change in $\mathrm{O}: \mathrm{C}$ during the functionalization processes can then be calculated.

For the fragmentation kernel, the fragmentation fraction of the products was assumed to depend on the $\mathrm{O}: \mathrm{C}$ ratio as

$$
\beta=(\mathrm{O}: \mathrm{C})^{f_{\mathrm{c}}},
$$


where $f_{\mathrm{c}}=1 / 6$ (Jimenez et al., 2009). The cleavage site was assumed to take place randomly at any of the carbon bonds with equal probability (e.g., Jimenez et al., 2009). The simplest way to model $\mathrm{O}: \mathrm{C}$ of the fragments is to assign the same $\mathrm{O}: \mathrm{C}$ ratio as the parent, such that the products increase in volatility only (Roldin et al., 2011). Their distribution can be estimated by interpolating the carbon number of the fragments between the two adjacent volatility bins with different carbon numbers. The products with volatilities greater than the highest $C_{i}^{*}$ of the model setting were assumed to be completely volatile and their subsequent products were assumed to stay in the gas phase only.

An alternative method to modeling the fragmentation processes assumes that the fragments are more volatile than the reactant and some fragments have higher $\mathrm{O}: \mathrm{C}$ than the reactants (e.g., Murphy et al., 2012b; and Donahue et al., 2012a). The midpoint of the $C_{i}^{*}$ (from the reactant $C_{i}^{*}$ to the largest $C_{i}^{*}$ defined in the model, $\left.C_{i, \max }^{*}\right), C_{i \text {,midpoint }}^{*}$, is used to distinguish heavy fragments (with volatilities lower than $C_{i \text {,midpoint }}^{*}$ ) and light fragments (with volatilities higher than $C_{i \text {,midpoint }}^{*}$ ). The $\mathrm{O}: \mathrm{C}$ of the heavy fragments is unchanged while those of the light fragments move diagonally towards $C_{i, \max }^{*}$ (Fig. S1). Then the radical portion of the fragments is functionalized in the same way as the reactant. For example, with a radical fraction $\left(f_{\text {radical }}\right)$ of $60 \%$, only $60 \%$ of the fragments are radicals that are functionalized after the fragmentation. In this work, the first method was used in the base-case original model (OM) while the second one was also tested and compared as the modified model (MM) (see Sect. 3.3.1).

\subsection{Global sensitivity analysis}

The sensitivity of the base-case original 2D-VBS SOA model to 13 parameters (Table 2) was explored for one select case with an initial gas-phase $\alpha$-pinene concentration of $281 \mu \mathrm{g} \mathrm{m}^{-3}$. Compared to the parameters listed in Table 2, other parameters associated with initial conditions (i.e., temperature, pressure, concentrations of $\mathrm{O}_{3}$ and $\alpha$-pinene) and rate coefficients of reactions of $\alpha$-pinene with $\mathrm{OH}$ and $\mathrm{O}_{3}$ were not included because their uncertainties are generally small (up to $\pm 20 \%, 1 \sigma$ confidence level). Additional simulations confirm that varying these parameters within their uncertainties only changes modeled $C_{\mathrm{OA}}$ and $\mathrm{O}: \mathrm{C}$ by up to $4.7 \%$ and $0.4 \%$, respectively.

The ranges over which these parameters were varied are summarized in Table 2 and explained briefly below. All uncertainties in this paper are reported at $1 \sigma$ confidence limits. The relative error of $\alpha_{i}$ was reported to be $9 \%$ (Pathak et al., $2007)$, leading to an estimated uncertainty of $\pm 20 \%$. The uncertainty of $n_{\mathrm{C}}$ was estimated to be $\pm 15 \%$ (i.e., greater than \pm 1 carbon number for $n_{\mathrm{C}} \geq 7$ ). The numbers of $C_{i}^{*}$ bins are varied from 8 to 12 , and the number of $\mathrm{O}: \mathrm{C}$ bins are varied from 10 to 14 bins so that the highest $C_{i}^{*}$ and $\mathrm{O}: \mathrm{C}$ of the 2-D space are varied accordingly. Since there is generally no uncertainty assessment available for most of these parameters, perturbation ranges were assigned based on different values from previous studies or simply with broad ranges of possible values. Initial $\mathrm{O}: \mathrm{C}\left(\mathrm{O}: \mathrm{C}_{i}\right)$ and molecular weights of first-generation oxidized products were varied within ranges of $0.2-0.5$ and $150-200 \mathrm{~g} \mathrm{~mol}^{-1}$, respectively, covering the reported values in Chan et al. (2009). The rate coefficients of homogeneous oxidation by $\mathrm{OH}$ and $\mathrm{O}_{3}$ and heterogeneous uptake by $\mathrm{OH}$ were perturbed within broad ranges of $(0.2-5) \times 10^{-11},(0.2-5) \times 10^{-17}$, and $(0.2-$ 5) $\times 10^{-12} \mathrm{~cm}^{3} \mathrm{molec}^{-1} \mathrm{~s}^{-1}$, respectively. The fragmentation coefficient $\beta=(\mathrm{O}: \mathrm{C})^{f_{\mathrm{c}}}$ was varied using a range of $f_{\mathrm{c}}$ from 0.1 to 0.5 . For the probability of oxygen addition during the functionalization process, a broad range of $0-0.5$ was assumed for both adding one $\left(P_{1 \mathrm{O}}\right)$ and two atoms $\left(P_{2 \mathrm{Os}}\right)$ while the probability of adding three atoms $\left(P_{30 \mathrm{~s}}\right)$ was simply calculated by $1-P_{1 \mathrm{O}}-P_{2 \mathrm{Os}}$. Therefore only the independent $P_{1 \mathrm{O}}$ and $P_{2 \mathrm{O}}$ were included in the sensitivity analysis.

The sensitivity of this SOA model was evaluated using a global sensitivity analysis (GSA) method by varying the values of model parameters simultaneously and quantifying their relative contribution to the modeled $C_{\mathrm{OA}}$ and $\mathrm{O}: \mathrm{C}$. The GSA method used here is called random sampling-high dimensional model representation (RS-HDMR) (Li et al., 2010 and reference therein). For a model with $n$ parameters, the sensitivity results are expressed by first-order, second-order, and higher-order sensitivity indices $\left(S_{i}, S_{i j}, \ldots, S_{12 \ldots n}\right)$ to represent the relative contribution from individual parameter $x_{i}$, parameter pair $x_{i}$ and $x_{j}$, and so forth, respectively:

$\sum_{i=1}^{n} S_{i}+\sum_{1 \leq i<j \leq n} S_{i j}+\ldots+S_{12 \ldots n}=1$.

The importance of $x_{i}$ can hence be ranked by the total sensitivity $S_{T i}$, which is defined to be the sum of all sensitivities (first-order and higher-order) involving $x_{i}$ (Saltelli et al., 2008). This method has been applied in different model systems (e.g., Chen and Brune, 2012) with up to hundreds of parameters and was able to efficiently apportion the sources of model uncertainty. For this SOA model, the Monte Carlo simulations were run 1000 times with the 13 model parameters varied randomly and independently over their uncertainty ranges and the corresponding input-output matrix was analyzed by ExploreHD (Aerodyne Inc.) to probe their impact on model results.

\section{Results and discussion}

\subsection{Model-measurement comparison}

The modeled $C_{\mathrm{OA}}$ and $\mathrm{O}: \mathrm{C}$ ratios are compared to measurements at the same levels of $\mathrm{OH}$ exposure (Fig. 1). In general, half of the measured and modeled $C_{\mathrm{OA}}$ values agree within $\pm 28 \%$ and most of the data agree within $\pm 49 \%$, with a correlation coefficient $R$ of 0.79 (Fig. 1a). Larger 


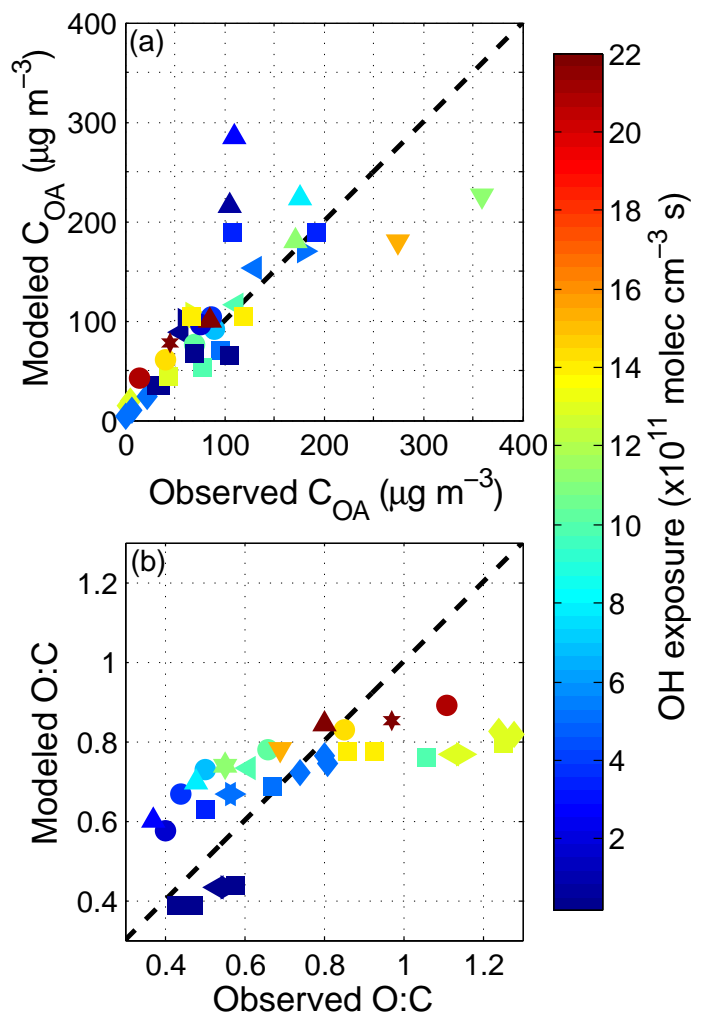

Fig. 1. The comparison of modeled and measured (a) $C_{\mathrm{OA}}$ and (b) $\mathrm{O}: \mathrm{C}$ with different initial conditions of PAM chamber $\left(\mathrm{RH}=20-25 \%\right.$ and $\mathrm{O}_{3}=8$ ppmv cases: initial $\alpha$-pinene of $23-114 \mu \mathrm{g} \mathrm{m}^{-3}$ (diamonds), $227 \mu \mathrm{g} \mathrm{m}^{-3}$ (squares), $443 \mu \mathrm{g} \mathrm{m}^{-3}$ (left-pointing triangles), $481-493 \mu \mathrm{g} \mathrm{m}^{-3}$ (right-pointing triangles); $\mathrm{RH}=30-40 \%$ and $\mathrm{O}_{3}=20$ ppmv cases: $281 \mu \mathrm{g} \mathrm{m}^{-3}$ (circles), $556 \mu \mathrm{g} \mathrm{m}^{-3}$ (stars), $695 \mu \mathrm{g} \mathrm{m}^{-3}$ (upward-pointing triangles), $833 \mu \mathrm{g} \mathrm{m}^{-3}$ (downward-pointing triangles)). The measurements of $C_{\mathrm{OA}}$ are calculated from the averages of AMS and SMPS measurements.

model-measurement discrepancy (modeled-to-observed ratio ranging from 0.6 to 2.6) was observed at different levels of $\mathrm{OH}$ exposure for three cases with $\triangle \mathrm{VOC}$ of 227,695 and $833 \mu \mathrm{g} \mathrm{m}^{-3}$. The model results of the $\Delta \mathrm{VOC}=281 \mu \mathrm{g} \mathrm{m}^{-3}$ case, which have representative behavior in $C_{\mathrm{OA}}$ and $\mathrm{O}: \mathrm{C}$ prediction, are shown in Fig. 2. The model was able to reproduce the $C_{\mathrm{OA}}$ trend of a rapid increase at lower $\mathrm{OH}$ exposure followed by a slower decrease at higher $\mathrm{OH}$ exposure, with modeled-to-observed $C_{\mathrm{OA}}$ ratios of 1.0-1.3, although the model tends to overpredict the SOA concentration at high $\mathrm{OH}$ exposure by a factor of $\sim 2$. The model-measurement agreement is generally acceptable considering the uncertainties associated with both the experiments and modeling.

The trend in modeled $\mathrm{O}: \mathrm{C}$ with respect to measured $\mathrm{O}: \mathrm{C}$ is different (Fig. 1b). Modeled and measured $\mathrm{O}: \mathrm{C}$ values are correlated $(R=0.68)$, but the trend between modeled versus measured $\mathrm{O}: \mathrm{C}$ values is nonlinear. The model systematically overpredicts low $\mathrm{O}: \mathrm{C}$ ratios $(\mathrm{O}: \mathrm{C} \sim 0.4-0.6)$ by as much as
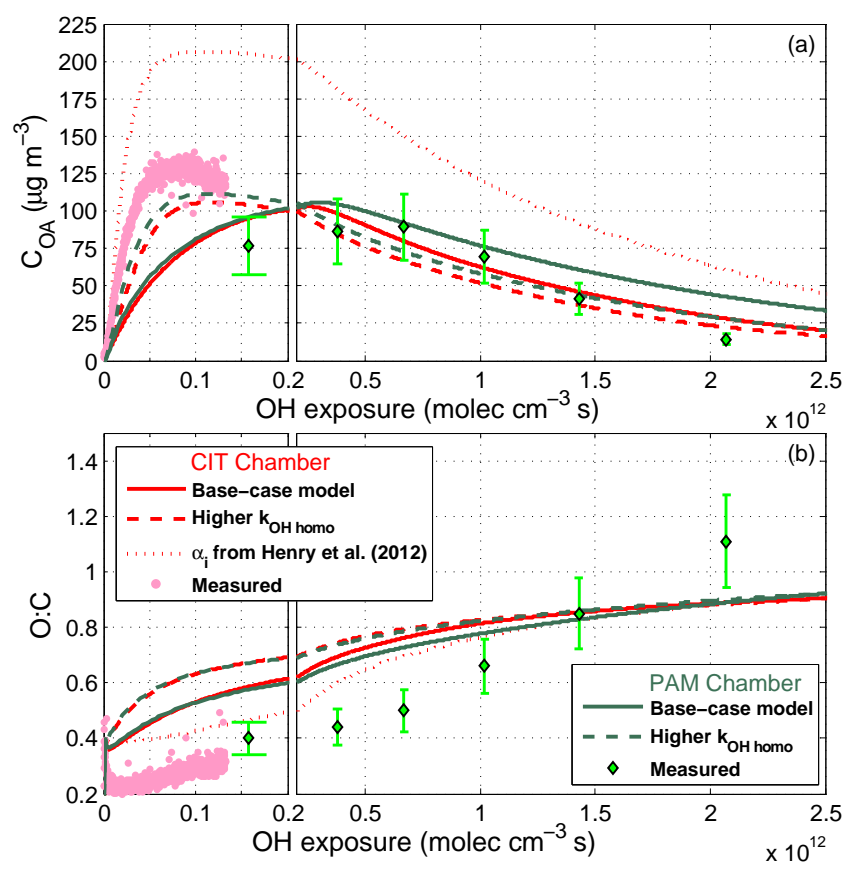

Fig. 2. The comparison of modeled and measured (a) $C_{\mathrm{OA}}$ and (b) $\mathrm{O}: \mathrm{C}$ in PAM chamber $\left(\triangle \mathrm{VOC}=281 \mu \mathrm{g} \mathrm{m}^{-3}\right)$ and CIT chamber $\left(\Delta \mathrm{VOC}=262 \mu \mathrm{g} \mathrm{m}^{-3}, \mathrm{Ng}\right.$ et al., 2007). The error bars denote the $1 \sigma$ uncertainty of the PAM measurements. Note that different scaling of $\mathrm{OH}$ exposure is used for $\mathrm{x}$-axis to show the results at lower and higher $\mathrm{OH}$ exposure levels.

$53 \%$, and underpredicts high $\mathrm{O}: \mathrm{C}$ ratios $(\mathrm{O}: \mathrm{C} \sim 1.0-1.3)$ by up to $36 \%$. As shown by the select case in Fig. 2b, the modeled and measured $\mathrm{O}: \mathrm{C}$ values follow different trends as a function of $\mathrm{OH}$ exposure. The modeled $\mathrm{O}: \mathrm{C}$ first increases rapidly and then more slowly, while the measured $\mathrm{O}: \mathrm{C}$ increases slowly at first and then more rapidly. The possible causes of this effect will be discussed later in the paper (see Sect. 3.3).

To evaluate SOA formation at lower $\mathrm{OH}$ exposures than those used in the PAM chamber experiments, our basecase model was also applied to an $\alpha$-pinene SOA experiment conducted in the Caltech environmental chamber (CIT) under low- $\mathrm{NO}_{\mathrm{x}}$ conditions (Ng et al., 2007, 2010; Lambe et al., 2011). In the CIT experiment, an initial $\alpha$-pinene concentration of $47.5 \mathrm{ppbv}$ was used, $[\mathrm{OH}]$ was about $3 \times$ $10^{6}$ molec $\mathrm{cm}^{-3}$, RH equaled $6.2 \%, \mathrm{O}_{3}$ was produced from the chamber walls at a rate of $\sim 1 \mathrm{ppbv} \mathrm{min}^{-1}$, and the chamber was seeded with ammonium sulfate particles. The measured and modeled $C_{\mathrm{OA}}$ and $\mathrm{O}: \mathrm{C}$ results of CIT are compared with the select case of PAM in Fig. 2 since the $\triangle$ VOC amounts are comparable $\left(\sim 262 \mu \mathrm{g} \mathrm{m}^{-3}\right.$ in CIT and $281 \mu \mathrm{g} \mathrm{m}^{-3}$ in PAM). The measured results with CIT and PAM conditions are broadly consistent as a function of $\mathrm{OH}$ exposure. Differences between other experimental conditions such as UV intensity and relative humidity (e.g., Presto et al., 2005; Pathak et al., 2007; and Henry and Donahue, 


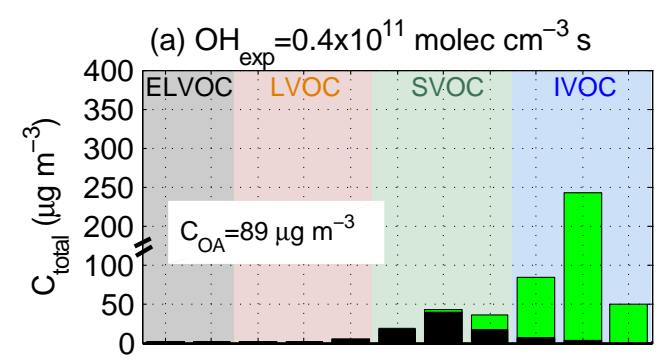

(b) $\mathrm{OH}_{\exp }=2.8 \times 10^{11} \mathrm{molec} \mathrm{cm}^{-3} \mathrm{~s}$
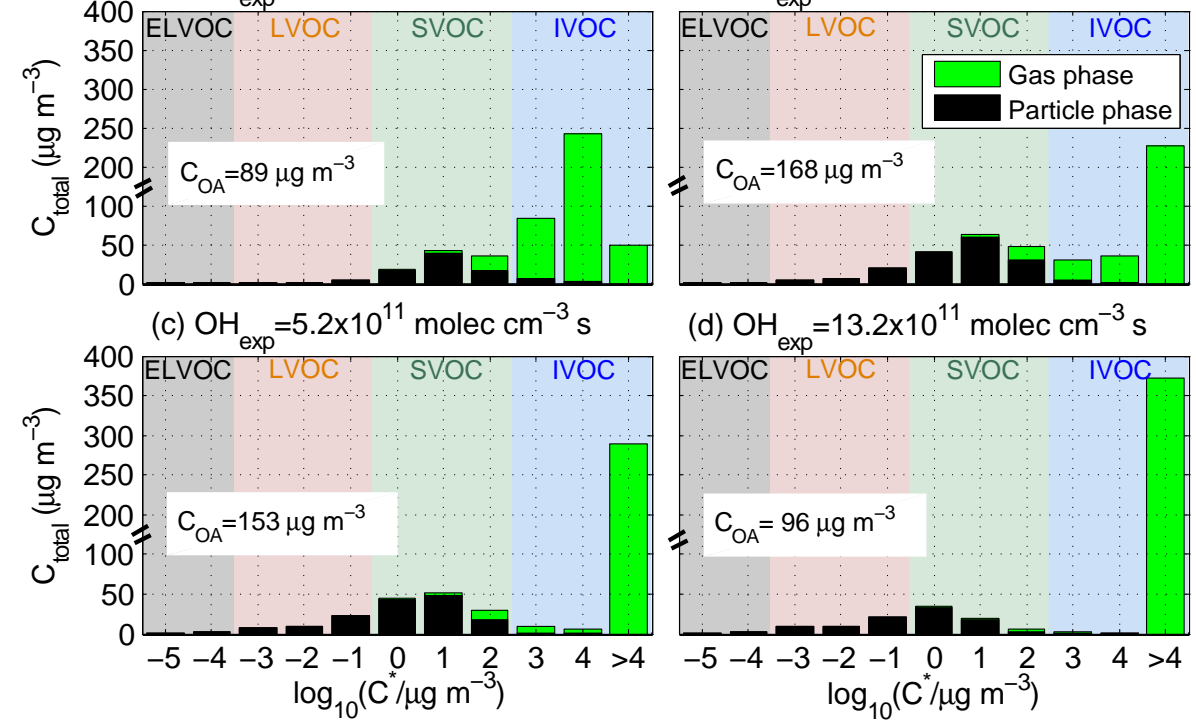

Fig. 3. The modeled variation of the volatility of the products generated from the oxidation of $\alpha$-pinene in the PAM chamber. Initial conditions: $\triangle \mathrm{VOC}=443 \mu \mathrm{g} \mathrm{m}^{-3}, \mathrm{RH}=20 \%, \mathrm{O}_{3}=8 \mathrm{ppmv}$. The mass of products with $C_{i}^{*}>10^{4} \mu \mathrm{g} \mathrm{m}^{-3}$ were calculated based on carbon mass conservation and were assumed to stay in gas phase and not participate in further oxidation. The volatility classes of organics defined by Donahue et al. (2012b) are used here.

2011) may contribute to any inconsistencies between CIT and PAM chamber results.

The model-measurement agreement of $C_{\mathrm{OA}}$ in the CIT chamber can be further improved by adjusting some parameters in the model. For example, by increasing the assumed gas-phase $\mathrm{OH}$ oxidation rate coefficient from $1 \times 10^{-11}$ to $4 \times 10^{-11} \mathrm{~cm}^{3} \mathrm{molec}^{-1} \mathrm{~s}^{-1}$, which was the highest $\mathrm{OH}$ homogeneous rate coefficient assumed in previous VBS modeling studies (e.g., Robinson et al., 2007; and Shrivastava et al., 2011), the model generally reproduces the $C_{\mathrm{OA}}$ in both CIT and PAM with average relative errors of $28 \%$ and $39 \%$, respectively (Fig. 2a). However, with a more recent parameterization of first-generation product yields of $\alpha$-pinene oxidation (Henry et al., 2012), which are sensitive to the experimental conditions (e.g., Presto et al., 2005; Pathak et al., 2007; and Henry and Donahue, 2011), the model significantly overpredicts the $C_{\mathrm{OA}}$ in the CIT (e.g., $C_{\mathrm{OA}}$ peak modeled at $48 \%$ higher than the measurement). It also should be noted that the $C_{\mathrm{OA}}$ measurements in the CIT were corrected for wall loss with first-order size-dependent coefficients (Ng et al., 2007). Therefore the uncertainty of this correction combined with measurement uncertainties in both the CIT and PAM might partially explain the discrepancy of the $C_{\mathrm{OA}}$ peaks.

Figure $2 \mathrm{~b}$ shows that the modeled $\mathrm{O}: \mathrm{C}$ is overpredicted at low $\mathrm{OH}$ exposure in the CIT chamber as well as in the PAM chamber despite the adjustments of $\mathrm{OH}$ homogeneous oxidation rate coefficient and first-generation products yields. This model-measurement discrepancy of $\mathrm{O}: \mathrm{C}$ is consistent with previous model results from another environmental chamber (Donahue et al., 2012a). These model adjustments also confirm that the modeled $C_{\mathrm{OA}}$ and $\mathrm{O}: \mathrm{C}$ are highly sensitive to the model input parameters (Fig. 2). In Sect. 3.3, we perform a detailed sensitivity analysis of the model parameters listed in Table 2 to provide insight into application of the 2D-VBS model to laboratory SOA measurements.

\subsection{The growth and evolution of SOA}

One of the advantages of the 2D-VBS is the ability to explicitly model the volatility and oxidation level $(\mathrm{O}: \mathrm{C})$ of $\alpha$-pinene oxidation products as a function of $\mathrm{OH}$ exposure. We start by examining trends in SOA volatility distributions as a function of $\mathrm{OH}$ exposure in 1D-VBS space (Fig. 3), with $\Delta \mathrm{VOC}=443 \mu \mathrm{g} \mathrm{m}^{-3}$. At a low $\mathrm{OH}$ exposure of $4 \times 10^{10} \mathrm{molec} \mathrm{cm}^{-3} \mathrm{~s}$, the composition of the total products $C_{\text {total }}$ is primarily determined by the stoichiometric yields of first-generation products, which are mainly gas-phase intermediate volatility organic compounds (IVOCs) (Fig. 3a). The less volatile products condense into the particle phase to form SOA products, which are mostly semivolatile organic compounds (SVOCs). As the $\mathrm{OH}$ exposure increases to $2.8 \times$ $10^{11}$ molec $\mathrm{cm}^{-3} \mathrm{~s}$ (Fig. 3b), the $\alpha$-pinene oxidation products undergo functionalization, which reduces their volatility and increases the yield of low volatility organic compounds (LVOCs) and SVOCs (Fig. 3b) so that SOA mass reaches its peak. As the $\mathrm{OH}$ exposure continues to increase, the SOA mass decreases slightly at $5.2 \times 10^{11} \mathrm{OH} \mathrm{cm}^{-3} \mathrm{~s}$ (Fig. 3c) and decreases further at an $\mathrm{OH}$ exposure of $1.3 \times 10^{12} \mathrm{OH} \mathrm{cm}^{-3} \mathrm{~s}$ 


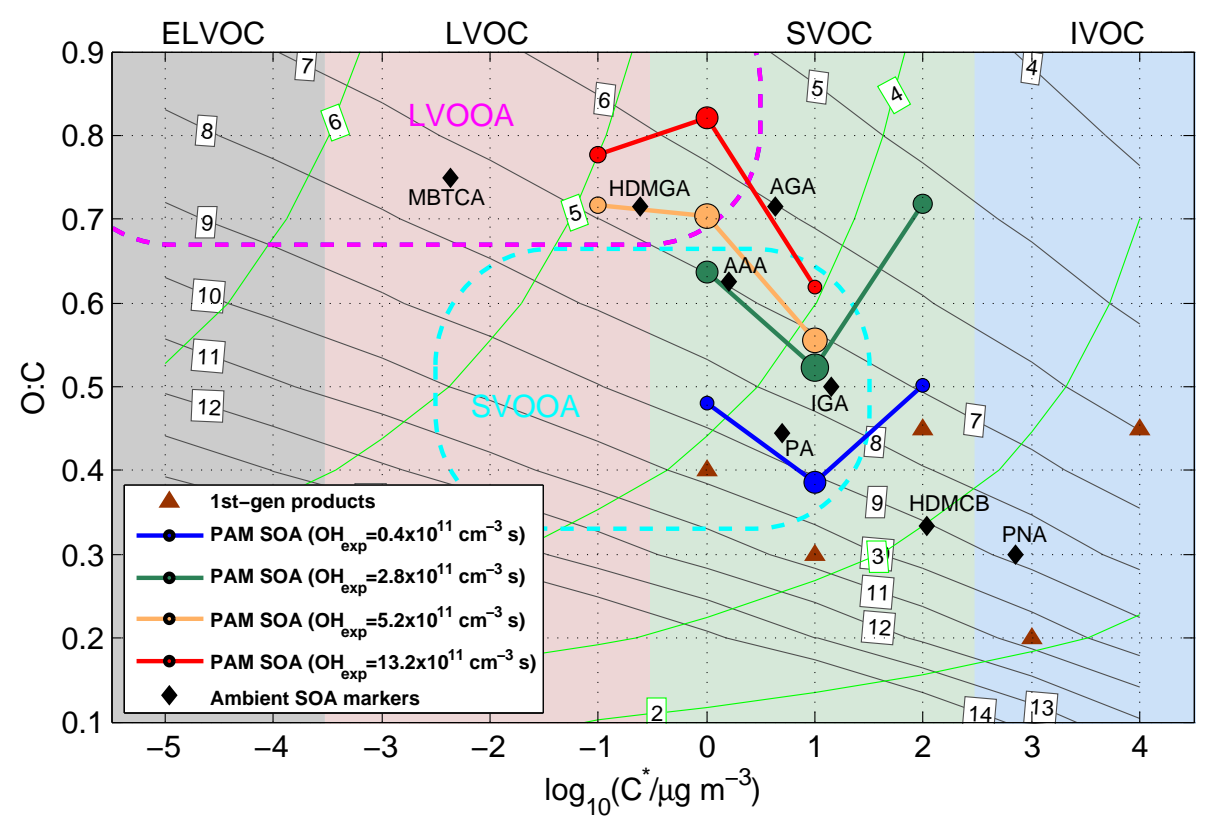

Fig. 4. The evolution of particle-phase mass and $\mathrm{O}: \mathrm{C}$ simulated from the oxidation of $\alpha$-pinene $\left(\Delta \mathrm{VOC}=443 \mu \mathrm{g} \mathrm{m} \mathrm{m}^{-3}\right)$. The $2 \mathrm{D}-\mathrm{VBS}$ space, classes of VOCs and OOA, and the contours (gray: carbon numbers; green: oxygen numbers) are adapted from Donahue et al. (2012b). The circles show the three most abundant products grouped in different volatility bins (contributing over $74 \%$ to the total SOA mass) for each of four levels of $\mathrm{OH}$ exposure in Fig. 2. The size of each circle indicates the relative particle-phase mass of the bulk products (see Fig. 2). The black diamonds denote the markers of ambient SOA from the photooxidation of $\alpha$-pinene: pinonic acid (PNA); 3-(2-hydroxyethyl)-2,2dimethylcyclobutane carboxylic acid (HDMCB); pinic acid (PA); 3-isopropylglutaric acid (IGA); 3-acetyladipic acid (AAA); 3-acetylglutaric acid (AGA); 3-hydroxy-4,4-dimethylglutaric acid (HDMGA); and 3-methyl-1,2,3-butanetricarboxylic (MBTCA) (El Haddad et al., 2012 and references therein). The volatility of these markers were estimated at $298 \mathrm{~K}$ based on the SIMPOL method (Pankow and Asher, 2008).

(Fig. 3d). This SOA decrease along with the increase of the $\mathrm{O}: \mathrm{C}$ from 0.61 to 0.77 suggests the importance of the fragmentation reactions that increase product volatility and decrease the yield of LVOCs and SVOCs, while the fragmentation coefficient $\beta$ is greater than 0.92 . The fragmentation reactions are favored by the products with higher oxidation states (Jimenez et al., 2009; Kroll et al., 2009; Lambe et al., 2012), as is evident from the increase in mass of products with $C_{i}^{*}>1 \times 10^{4} \mu \mathrm{g} \mathrm{m}^{-3}$ as a function of $\mathrm{OH}$ exposure.

Figure 4 shows the particle-phase products from Fig. 3 plotted in 2D-VBS space (Donahue et al., 2012b). At each $\mathrm{OH}$ exposure, the three most abundant SOA products are shown, and in all cases contribute $74 \%$ or more of the total particle-phase mass. We note that at each $\mathrm{OH}$ exposure, oxidation products with $C_{i}^{*}$ of $10 \mu \mathrm{g} \mathrm{m}^{-3}$ have lower O : C than corresponding oxidation products at $C_{i}^{*}$ of $0.1,1$, and/or $100 \mu \mathrm{g} \mathrm{m}^{-3}$. This difference arises from the formation of oxidation products that have a $C_{i}^{*}$ of $10 \mu \mathrm{g} \mathrm{m}^{-3}$ and come from the functionalization of the first-generation oxidation products $\left(\mathrm{O}: \mathrm{C} \sim 0.2, C_{i}^{*} \sim 10^{3} \mu \mathrm{g} \mathrm{m}^{-3}\right.$ ) prior to subsequent evolution with increasing $\mathrm{OH}$ exposure.

Starting from the first-generation oxidation products (see Table 1), the modeled SOA mass and $\mathrm{O}: \mathrm{C}$ ratio move with increasing $\mathrm{OH}$ exposure from the bottom right-hand corner to the top left-hand corner of the 2D-VBS phase space. As in- dicated by the carbon number and oxygen number isopleths, the average carbon number drops gradually from 10 to $\sim 6$, while the average oxygen number increases from around 3.5 to 4.5. We note that PAM-generated SOA follows a similar 2D-VBS trajectory as ambient SOA (Jimenez et al., 2009; Donahue et al., 2012b). Thus the volatility and oxidation states of modeled and measured SOA in the PAM chamber are generally consistent with the measured markers of $\alpha$ pinene SOA volatility and oxidation states in the atmosphere (Fig. 4).

\subsection{Sensitivity study}

As discussed in Sect. 2.2, several assumptions and simplifications have been used in this 2D-VBS model that could be responsible for the differences in the behavior of measured and modeled $\mathrm{O}: \mathrm{C}$ as a function of $\mathrm{OH}$ exposure. To investigate the influence of model configuration and model input parameters on modeled $C_{\mathrm{OA}}$ and $\mathrm{O}: \mathrm{C}$ values, we performed additional simulations (1) under measured temperature $T_{\mathrm{obs}}$, or (2) using different 2D-VBS model configurations, and (3) conducted a global sensitivity analysis to determine model uncertainty and the model parameters to which the modeled $C_{\mathrm{OA}}$ and $\mathrm{O}: \mathrm{C}$ are most sensitive. These tests 
provide guidance for future model development and laboratory research.

\subsubsection{Temperature sensitivity}

To probe the impact of temperature and $\Delta H_{\mathrm{v}}$ variations on the model-measurement agreement, 12 additional simulations were run for the select case $\left(\triangle \mathrm{VOC}=281 \mu \mathrm{g} \mathrm{m}^{-3}\right)$ at six measured temperatures $T_{\text {obs }}(295-307 \mathrm{~K})$ with either a constant effective $\Delta H_{\mathrm{v}}\left(30 \mathrm{~kJ} \mathrm{~mol}^{-1}\right)$ or $C_{i}^{*}$-dependent $\Delta H_{\mathrm{v}}$ (Epstein et al., 2010). The model results show that the model with the constant $\Delta H_{\mathrm{v}}$ does not produce a significant variation in modeled $C_{\mathrm{OA}}$ (within $6 \%$ ) and $\mathrm{O}: \mathrm{C}$ (within $1 \%$ ) for the range of $T_{\text {obs }}$. For the model with $C_{i}^{*}$-dependent $\Delta H_{\mathrm{v}}$, the modeled $C_{\mathrm{OA}}$ decreases by up to $35 \%$ at higher temperatures $(303-307 \mathrm{~K})$ and higher $\mathrm{OH}$ exposures, as a result of the shift of $C_{i}^{*}$. Meanwhile, the modeled $\mathrm{O}: \mathrm{C}$ only varies within $3 \%$, compared to the model results at $298 \mathrm{~K}$. Therefore the model performance was compared by the model-toobserved ratios of $C_{\mathrm{OA}}$ only, using the uncorrected measurements for the additional model results (Fig. S2). In general, relatively consistent model-to-observed ratios (within 7\%) were obtained while the model accounts for the temperature increasing up to $303 \mathrm{~K}$. For the temperature at $307 \mathrm{~K}$ and a high $\mathrm{OH}$ exposure of $2.1 \times 10^{12} \mathrm{molec}^{-3} \mathrm{~s}, C_{\mathrm{OA}}$ predicted by the model with $C_{i}^{*}$-dependent $\Delta H_{\mathrm{v}}$ is in better agreement with the measurement (model-to-observed ratio decreases from 3.0 to 2.3), although significant overprediction remains. Therefore the temperature correction used in this work gives results comparable to more detailed treatments of temperature for $\mathrm{OH}$ exposures up to $1.4 \times 10^{12} \mathrm{molec} \mathrm{cm}^{-3} \mathrm{~s}$. For higher temperature and $\mathrm{OH}$ exposure, the discrepancy caused by the constant temperature correction can partially explain the overprediction of $C_{\mathrm{OA}}$.

\subsubsection{Modified model configuration}

An alternative model configuration (MM, see Sect. 2.2) was also tested for the select case, in which lighter products of fragmentation reactions were assumed to have higher $\mathrm{O}: \mathrm{C}$ than the reactants (e.g., Murphy et al., 2012a; and Donahue et al., 2012a), compared to the assumption that all fragments have the same $\mathrm{O}: \mathrm{C}$ as the reactants in the base-case original model $(\mathrm{OM})$. Additionally, MM treats $60 \%$ of the fragments as organic radicals that are subsequently functionalized $\left(f_{\text {radical }}=60 \%\right)$. Compared to OM results, MM increases both modeled $C_{\mathrm{OA}}$ and $\mathrm{O}: \mathrm{C}$ by $17 \%$ and $10 \%$, respectively, which does not improve model-measurement agreement (Fig. 5). Several parameters of MM were hence varied to probe their impact on the SOA modeling results (see Fig. 5 for selected results).

Varying one or two of the model parameters generally increase or decrease both modeled $C_{\mathrm{OA}}$ and $\mathrm{O}: \mathrm{C}$. For instance, we extended the number of volatility bins $n_{x}$ to 13 (i.e., largest $C_{i}^{*}$ of $10^{7} \mu \mathrm{g} \mathrm{m}^{-3}$ ) or the number of $\mathrm{O}: \mathrm{C}$ bins

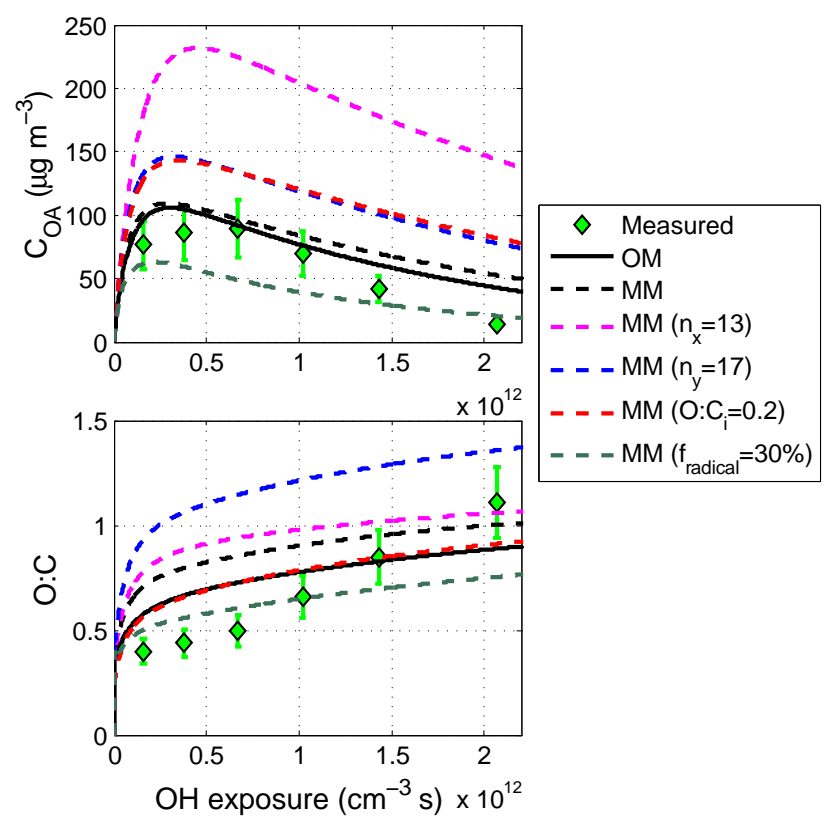

Fig. 5. The modeled result of $C_{\mathrm{OA}}$ and $\mathrm{O}: \mathrm{C}$ from both the original model (OM, denoted by solid lines) and modified model (MM, denoted by dash lines) (Murphy et al., 2012a; Donahue et al., 2012a) with the initial $\alpha$-pinene of $281 \mathrm{\mu g} \mathrm{m}^{-3}$ when some parameters are varied (see legend).

$n_{y}$ to 17 (i.e., largest $\mathrm{O}: \mathrm{C}$ of 1.8 ). This change increases modeled $C_{\mathrm{OA}}$ by up to a factor of 2.4 and increases modeled O : C by up to $34 \%$. For the $C_{i}^{*}$ axis, the modeled oxidation of the products with high $C_{i}^{*}$ of $10^{5}-10^{7} \mu \mathrm{g} \mathrm{m}^{-3}$ shifts the SOA mass in the direction of lower volatility and higher oxidation states through continuous functionalization processes. For the $\mathrm{O}: \mathrm{C}$ axis, the higher $\mathrm{O}: \mathrm{C}$ ratios up to 1.8 become assigned to light fragments and further functionalization can evolve the SOA to lower volatility and higher oxidation states. Another example is when $f_{\text {radical }}$ decreases from 60 to $30 \%$, the modeled $C_{\mathrm{OA}}$ and $\mathrm{O}: \mathrm{C}$ are lowered on average by $53 \%$ and $27 \%$, respectively. One of the parameters found to have different impacts on modeled $C_{\mathrm{OA}}$ and $\mathrm{O}: \mathrm{C}$ is the $\mathrm{O}: \mathrm{C}$ of first-generation products. Adjusting this parameter to a lower specific value (e.g., 0.2) increases the modeled $C_{\mathrm{OA}}$ by $43 \%$ and decreases the modeled O:C by $13 \%$ since more products are produced with lower $\mathrm{O}: \mathrm{C}$, which also decreases the fragmentation branch ratio.

Applying this alternative model configuration (MM) and adjusting these model parameters does not improve modelmeasurement agreement for $C_{\mathrm{OA}}$ or $\mathrm{O}: \mathrm{C}$ relative to the basecase model. In many cases, the agreement is worse (e.g., average relative error of $\mathrm{MM}$ is higher than $\mathrm{OM}$ by a factor of 1.6 and 3.3 for $C_{\mathrm{OA}}$ and $\mathrm{O}: \mathrm{C}$, respectively). However, it is possible that some model parameters need to be varied together and/or more complex scenarios are required. For instance, similar to the fragmentation coefficient $\beta$, some parameters such as the probability of adding oxygen atoms and 

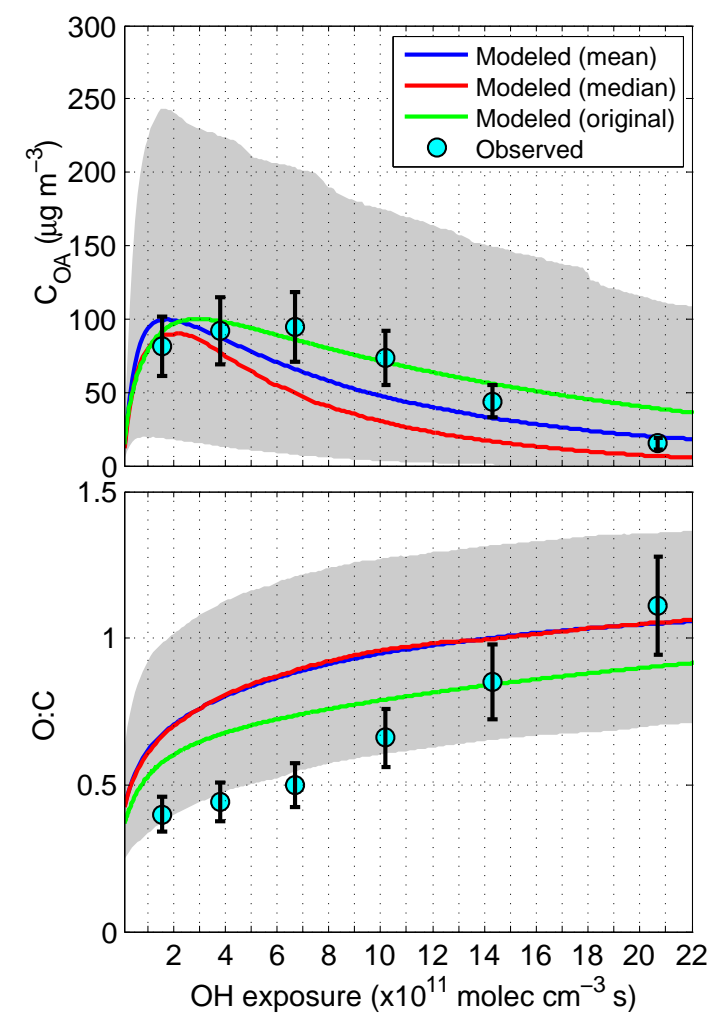

Fig. 6. The variation of modeled $C_{\mathrm{OA}}$ and $\mathrm{O}: \mathrm{C}$ resulting from the variation of model parameters of the base-case original model for the case with initial $\alpha$-pinene of $281 \mu \mathrm{g} \mathrm{m}^{-3}$. The gray shadow extends to the most extreme data points corresponding to 97.5 and 2.5 percentiles, that is, $95 \%$ coverage of the data. The error bars show the uncertainties of measured $C_{\mathrm{OA}}$ and $\mathrm{O}: \mathrm{C}$.

$f_{\text {radical }}$ might change with SOA oxidation state. To improve the model-measurement agreement of $C_{\mathrm{OA}}$ and $\mathrm{O}: \mathrm{C}$, the global sensitivity analysis in the following section may be able to provide some insight into which model parameters are the most influential and should be examined in more detail.

\subsubsection{Global sensitivity analysis}

Monte Carlo simulations were conducted in which the thirteen 2D-VBS model parameters (Table 2) were simultaneously perturbed to assess the range of possible modeled $C_{\mathrm{OA}}$ and $\mathrm{O}: \mathrm{C}$ values. Figure 6 shows the results as a function of $\mathrm{OH}$ exposure following 1000 Monte Carlo simulations. As expected, the range of modeled $C_{\mathrm{OA}}$ and $\mathrm{O}: \mathrm{C}$ values (gray region) covers a significantly wider phase space than singleparameter perturbations (Sect. 3.3.2). Since some parameters such as $C_{i, \max }^{*}$ and $P_{2 \mathrm{Os}}$ were varied significantly from their base-case values (Table 2), the median and mean values from the Monte Carlo simulations deviate from the original model for both $C_{\mathrm{OA}}$ and $\mathrm{O}: \mathrm{C}$. For instance, the average modeled value of $C_{\mathrm{OA}}$ is up to $50 \%$ lower than the base-case sim-

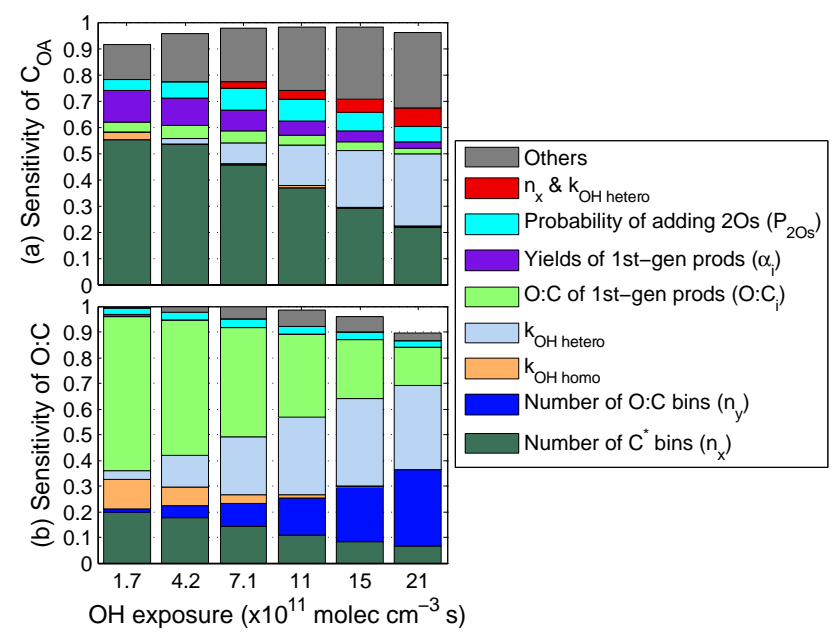

Fig. 7. The sensitivity of modeled (a) $C_{\mathrm{OA}}$ and (b) $\mathrm{O}: \mathrm{C}$ for the six cases that represent the evolution of SOA at different $\mathrm{OH}$ exposure levels of $(2-20) \times 10^{11}$ molec $\mathrm{cm}^{-3} \mathrm{~s}$. Only important model parameters (sensitivity greater than 0.05 for at least one case) are shown here.

ulation of $C_{\mathrm{OA}}$ at high $\mathrm{OH}$ exposure. On the other hand, the average modeled $\mathrm{O}: \mathrm{C}$ is $\sim 18 \%$ higher. A conservative model uncertainty estimate at $1 \sigma$ is $40-120 \%$ for $C_{\mathrm{OA}}$, which inversely correlates with the SOA mass $(R=-0.89)$, and $\sim 40 \%$ for $\mathrm{O}: \mathrm{C}$. In general, modeled and measured $C_{\mathrm{OA}}$ and $\mathrm{O}: \mathrm{C}$ agree well within their uncertainties.

However, there are differences. For $C_{\mathrm{OA}}$, the measured peak is at a slightly higher $\mathrm{OH}$ exposure than the modeled peak and at higher $\mathrm{OH}$ exposure, the measured $C_{\mathrm{OA}}$ is about half the modeled $C_{\mathrm{OA}}$ in the original model. For $\mathrm{O}: \mathrm{C}$, the difference in the shapes of curves of modeled and measured $\mathrm{O}: \mathrm{C}$ versus $\mathrm{OH}$ exposure is persistent and significant. A sensitivity study can provide guidance for the possible causes of these differences.

A global sensitivity analysis was performed at six $\mathrm{OH}$ exposures within the range of $\sim(2-20) \times 10^{11} \mathrm{molec} \mathrm{cm}^{-3} \mathrm{~s}$; a summary of measurements and results from base-case modeling and Monte Carlo simulations is shown in Table 3. The RS-HDMR method was conducted to compute up to thirdorder sensitivity, i.e., $S_{i}, S_{i j}$, and $S_{i j k}$, which represent the relative contribution from individual parameters, parameter pairs, and parameter triplets, respectively. For all of the six cases, the sums of the sensitivities $\left(\sum S_{i}+\sum S_{i j}+\sum S_{i j k}\right)$ are greater than 0.90 (Fig. 7), indicating that over $90 \%$ of model uncertainty can be attributed to the contribution from individual parameters and parameter pairs/triplets. The firstorder sensitivity dominates with $\sum S_{i}>0.62$ for $C_{\mathrm{OA}}$ and $\sum S_{i}>0.90$ for $\mathrm{O}: \mathrm{C}$, highlighting the significant contribution of individual parameters to the model uncertainty. The sensitivities of the most important model parameters (with sensitivity greater than 0.05 for at least one case) are shown in Fig. 7. 
Table 3. The variations of modeled SOA and $\mathrm{OH}$ exposure $\left(\mathrm{OH}_{\mathrm{exp}}\right)$ as a result of 1000 Monte Carlo simulations for the six cases with different $\mathrm{OH}$ exposure levels.

\begin{tabular}{|c|c|c|c|c|c|c|c|c|}
\hline \multirow[t]{2}{*}{$\#$} & \multicolumn{3}{|c|}{ Measurement } & \multicolumn{2}{|c|}{ Model } & \multicolumn{3}{|c|}{ Monte Carlo simulations } \\
\hline & $\underset{\left(\operatorname{molec} \mathrm{cm}^{-3} \mathrm{~s}\right)}{\mathrm{OH}_{\operatorname{cop}}}$ & $\mathrm{O}: \mathrm{C}$ & $\begin{array}{r}C_{\mathrm{OA}} \\
\left(\mu \mathrm{g} \mathrm{m}^{-3}\right)\end{array}$ & $\mathrm{O}: \mathrm{C}$ & $\begin{array}{c}C_{\mathrm{OA}} \\
\left(\mu \mathrm{g} \mathrm{m}^{-3}\right)\end{array}$ & $\begin{array}{c}\mathrm{OH}_{\exp } \\
\left(\operatorname{molec~} \mathrm{cm}^{-3} \mathrm{~s}\right)\end{array}$ & $\mathrm{O}: \mathrm{C}$ & $\begin{array}{r}C_{\mathrm{OA}} \\
\left(\mu \mathrm{g} \mathrm{m}^{-3}\right)\end{array}$ \\
\hline 1 & $1.6 \times 10^{11}$ & 0.40 & 116 & 0.58 & 92 & $(1.7 \pm 0.3) \times 10^{11}$ & $0.68 \pm 0.16$ & $100 \pm 63$ \\
\hline 2 & $3.8 \times 10^{11}$ & 0.44 & 125 & 0.67 & 98 & $(4.2 \pm 0.6) \times 10^{11}$ & $0.81 \pm 0.16$ & $87 \pm 63$ \\
\hline 3 & $6.7 \times 10^{11}$ & 0.50 & 113 & 0.74 & 86 & $(7.1 \pm 1.1) \times 10^{11}$ & $0.89 \pm 0.16$ & $68 \pm 58$ \\
\hline 4 & $1.0 \times 10^{12}$ & 0.66 & 81 & 0.79 & 71 & $(1.1 \pm 0.2) \times 10^{12}$ & $0.96 \pm 0.16$ & $51 \pm 52$ \\
\hline 5 & $1.4 \times 10^{12}$ & 0.85 & 43 & 0.84 & 56 & $(1.5 \pm 0.3) \times 10^{12}$ & $1.02 \pm 0.16$ & $36 \pm 47$ \\
\hline 6 & $2.1 \times 10^{12}$ & 1.11 & 12 & 0.90 & 39 & $(2.1 \pm 0.4) \times 10^{12}$ & $1.07 \pm 0.16$ & $24 \pm 39$ \\
\hline
\end{tabular}

The modeled SOA mass concentration, $C_{\mathrm{OA}}$, is most sensitive to the choice of the number of $C_{i}^{*}$ bins, $n_{x}$, especially for low $\mathrm{OH}$ exposure ( $S_{i}$ up to 0.55 ). This sensitivity occurs because increasing the number of bins increases $C_{i, \max }^{*}$. When $C_{i, \max }^{*}$ is less than $10^{4} \mu \mathrm{g} \mathrm{m}{ }^{-3}$, the initial products with volatility greater than $C_{i, \max }^{*}$ are excluded, which reduces the magnitude of semivolatile organics that would contribute to $C_{\mathrm{OA}}$. The $C_{\mathrm{OA}}$ sensitivity to the heterogeneous reaction rate coefficient, $k_{\mathrm{OH} \text { hetero }}$, is negligible at low $\mathrm{OH}$ exposure $\left(S_{i}<0.02\right)$, but grows to become the most important parameter at the highest $\mathrm{OH}$ exposure ( $S_{i}$ up to 0.27 ). This change in $k_{\mathrm{OH} \text { hetero }}$ occurs because at low $\mathrm{OH}$ exposure, $C_{\mathrm{OA}}$ is primarily influenced by the initial yields of first-generation oxidation products $\alpha_{i}$ ( $S_{i}$ up to 0.11 ). As the particle is further oxidized and more mass of oxidation products condenses to the particle phase, $C_{\mathrm{OA}}$ becomes more sensitive to the heterogeneous oxidation rate. Note also that $C_{\mathrm{OA}}$ becomes sensitive to the coupling between the $n_{x}$ and $k_{\mathrm{OH} \_ \text {hetero }}\left(S_{i j}\right.$ up to 0.07 ) since $n_{x}$ is critical in determining the mass of oxidation products in particle phase, which react with $\mathrm{OH}$ at the effective rate constant of $k_{\mathrm{OH} \text { hetero. }}$ It is interesting that the gasphase reaction rate coefficient $k_{\mathrm{OH} \_h o m o}$ has little impact on $C_{\mathrm{OA}}\left(S_{i}<0.03\right)$, which implies that the gas-phase reaction rates are sufficiently fast that they do not limit the oxidation rate and thus the change in $C_{\mathrm{OA}} . C_{\mathrm{OA}}$ is also sensitive to two other factors: the probability of functionalization with two oxygen atoms, $P_{2 \mathrm{Os}},\left(S_{i}=0.04-0.09\right)$ and the initial O : C of the first-generation products $\left(\mathrm{O}: \mathrm{C}_{i}\right)\left(S_{i}=0.02-0.05\right)$. The probability of adding more oxygen atoms is more influential (average $S_{i}$ of 0.07 and 0.02 for $P_{20 \text { s }}$ and $P_{10}$, respectively) since adding more oxygen atoms leads to a greater shift of the products to lower volatilities, which also covers a larger range of the volatility reduction (e.g., $1-3$ and 2-5 decades reduction in volatility by adding 1 or 2 oxygen atoms, respectively).

At low $\mathrm{OH}$ exposure, $\mathrm{O}: \mathrm{C}$ is most sensitive to $\mathrm{O}: \mathrm{C}_{i}\left(S_{i}\right.$ up to 0.60) followed by choice of the number of $C_{i}^{*}$ bins $n_{x}\left(S_{i}\right.$ up to 0.20$)$, and $k_{\mathrm{OH} \_ \text {homo }}\left(S_{i}\right.$ up to 0.12$)$. The sensitivity of $\mathrm{O}: \mathrm{C}$ to $\mathrm{O}: \mathrm{C}_{i}$ at low $\mathrm{OH}$ exposure is large be- cause $\mathrm{O}: \mathrm{C} \approx \mathrm{O}: \mathrm{C}_{i}$. The sensitivity to $n_{x}$ comes from different partitioning of products with different $\mathrm{O}: \mathrm{C}$ between the gas-phase and particle-phase. The gas-phase reaction rate $k_{\mathrm{OH} \text { homo }}$ is influential by increasing $\mathrm{O}: \mathrm{C}$ through the functionalization process. However, at high $\mathrm{OH}$ exposure, $\mathrm{O}: \mathrm{C}$ becomes less sensitive to these three parameters with $S_{i}$ gradually decreasing to $0.15,0.06$, and 0 for $\mathrm{O}: \mathrm{C}_{i}, n_{x}$, and $k_{\mathrm{OH} \text { homo }}$, respectively. Instead, $\mathrm{O}: \mathrm{C}$ becomes most sensitive to $k_{\mathrm{OH} \text { hetero }}\left(S_{i}\right.$ up to 0.33$)$, followed by $n_{y}\left(S_{i}\right.$ up to 0.30 ). The increased sensitivity to $n_{y}$ comes from that $n_{y}$ limits the highest $\mathrm{O}: \mathrm{C}$ (ranging from 1.0 to 1.4) SOA could reach as the aging process evolves SOA to higher oxidation states. Additional sensitivity runs indicate that modeled $\mathrm{O}: \mathrm{C}$ at high $\mathrm{OH}$ exposure $\left(2 \times 10^{12}\right.$ molec $\left.\mathrm{cm}^{-3} \mathrm{~s}\right)$ increases from 0.81 to 0.93 and 0.97 by varying the highest $\mathrm{O}: \mathrm{C}$ from 1.0 to 1.4 and 2.0, respectively. Therefore the upper limit of $\mathrm{O}: \mathrm{C}$ of at least 1.4 is needed to avoid artificially lowering the $\mathrm{O}: \mathrm{C}$ prediction by the original base-case model.

Both $C_{\mathrm{OA}}$ and $\mathrm{O}: \mathrm{C}$ are more sensitive to $k_{\mathrm{OH} \text { homo }}$ at low $\mathrm{OH}$ exposure, and more sensitive to $k_{\mathrm{OH} \text { hetero }}$ at high $\mathrm{OH}$ exposure. This sensitivity shift suggests that heterogeneous reactions become more important as the SOA becomes more oxidized. SOA is initially oxidized primarily in the gas phase by $\mathrm{OH}$ reactions and creates semivolatile oxidation products that partition with the particle phase, increasing $C_{\mathrm{OA}}$ and $\mathrm{O}: \mathrm{C}$. Further oxidation reduces the volatility of semivolatile oxidation products so that the gas-phase concentrations of the oxidation products decrease and therefore less homogeneous oxidation can occur. As a result, heterogeneous oxidation becomes more important relative to homogeneous oxidation. This result suggests that, in the atmosphere, the relative importance of heterogeneous $\mathrm{OH}$ reactions may increase with increasing exposure times and/or distance from sources.

\section{Conclusions}

Our implementation of the 2D-VBS model generally captures the observed behavior of $\alpha$-pinene SOA formation and evolution in a Potential Aerosol Mass chamber and the 
Caltech smog chamber within the uncertainties of the model and the measurements. The modeled SOA mass concentration, $C_{\mathrm{OA}}$, increases as functionalization reactions create more oxidized and less volatile VOC products and then decreases as fragmentation reactions create products that have higher volatility. In addition, the modeled SOA oxidation state, as indicated by $\mathrm{O}: \mathrm{C}$, increases in a way that is qualitatively consistent with the PAM chamber measurements. Furthermore, this modeled SOA aging is consistent with the SOA aging that is measured in the Caltech environmental chamber and in the atmosphere.

While the modeled and observed SOA O : $\mathrm{C}$ increase with $\mathrm{OH}$ exposure, the magnitude and functional form of the increase differ significantly. This discrepancy is probably not specific to the highly oxidizing environment in the PAM chamber because the same general trends were also observed in two large environmental chambers ( $\mathrm{Ng}$ et al., 2007; Donahue et al., 2012a). Thus it is likely that this discrepancy emerges from the model framework. A global sensitivity analysis has the potential to indicate the cause. The most important parameters for modeled $C_{\mathrm{OA}}$ and $\mathrm{O}: \mathrm{C}$ were found to be associated with the highest $C_{i}^{*}$ and $\mathrm{O}: \mathrm{C}$ values used to define the boundary of the 2D-VBS space, the initial mass yields and $\mathrm{O}: \mathrm{C}$ ratios of the products from the firstgeneration oxidation, particle-phase $\mathrm{OH}$ uptake rate, and the probability of adding oxygen atoms during the functionalization process.

However, none of the Monte Carlo simulations were able to reproduce the measured curvature of $\mathrm{O}: \mathrm{C}$, suggesting that either more parameters should be varied for the global sensitivity analysis or the model formulation should be changed. In addition to the 13 model parameters listed in Table 2, the model sensitivity to more parameters will be explored in future work, such as (1) alternative first-generation product yields representations (e.g., RH-dependent yields), (2) varied magnitudes of $C_{i}^{*}$ reduction following functionalization reactions, and (3) alternative representations of fragmentation coefficient (e.g., as in Cappa and Wilson, 2012).

For the model formulation, it is possible that some assumptions made for the current model are too simplified to represent the trajectory of SOA aging accurately. For instance, some of the model parameters such as the probability of adding oxygen or fragmentation could be a function of carbon number, molecular structure, volatility, and/or oxidation state of the organic products. In addition, the widely used assumption of instantaneous equilibrium partitioning may lead to overprediction of $C_{\mathrm{OA}}$ (Shiraiwa and Seinfeld, 2012) if the SOA is characterized by a solid phase state (Virtanen et al., 2010; Perraud et al., 2012; Saukko et al., 2012). Other assumptions that deserve more scrutiny include $\mathrm{OH}$ and $\mathrm{O}_{3}$ reactions causing the same products or using a gas-phase reaction rate coefficient to simulate heterogeneous chemistry instead of including microphysics and well as chemistry and using the same mechanisms for gas-phase and heterogeneous oxidation reactions. For example, the fragmentation branch- ing ratios in the heterogeneous reactions may be different from gas-phase reactions (Kroll et al., 2009). These assumptions will be tested in future work.

\section{Supplementary material related to this article is available online at: http://www.atmos-chem-phys.net/13/ 5017/2013/acp-13-5017-2013-supplement.pdf.}

Acknowledgements. We thank A. T. Ahern, D. R. Croasdale, J. P. Wright, and P. Massoli (BC/ARI) for contributions to the laboratory experiments, D. van Duin, T. Samuelson, and K. Christian (PSU) for producing the $\alpha$-pinene mixtures, O. Oluwole, C. Kolb, F. Bacon, and G. Li (ARI) for the ExplorerHD software that was used to compute global sensitivity. We also thank N. L. Ng (Georgia Tech) for Caltech chamber data. SC and WB acknowledge the support by the National Science Foundation grant AGS-0855135. ATL, PD and TBO acknowledge support by the Office of Science (BER), Department of Energy (Atmospheric Science Program) grants No. DE-SC0006980 and DE-FG02-05ER63995, and the Atmospheric Chemistry Program of the National Science Foundation grants No. ATM-0854916 and AGS-0904292.

Edited by: B. Ervens

\section{References}

Aiken, A. C., DeCarlo, P. F., Kroll, J. H., Worsnop, D. R., Huffman, J. A., Docherty, K. S., Ulbrich, I. M., Mohr, C., Kimmel, J. R., Sueper, D., Sun, Y., Zhang, Q., Trimborn, A., Northway, M., Ziemann, P. J., Canagaratna, M. R., Onasch, T. B., Alfarra, M. R., Prevot, A. S. H., Dommen, J., Duplissy, J., Metzger, A., Baltensperger, U., and Jimenez, J. L.: O/C and OM/OC Ratios of Primary, Secondary, and Ambient Organic Aerosols with HighResolution Time-of-Flight Aerosol Mass Spectrometry, Environ. Sci. Technol., 42, 4478-4485, 2008.

Atkinson, R., Baulch, D. L., Cox, R. A., Crowley, J. N., Hampson, R. F., Hynes, R. G., Jenkin, M. E., Rossi, M. J., Troe, J., and IUPAC Subcommittee: Evaluated kinetic and photochemical data for atmospheric chemistry: Volume II - gas phase reactions of organic species, Atmos. Chem. Phys., 6, 3625-4055, doi:10.5194/acp-6-3625-2006, 2006.

Aumont, B., Szopa, S., and Madronich, S.: Modelling the evolution of organic carbon during its gas-phase tropospheric oxidation: development of an explicit model based on a self generating approach, Atmos. Chem. Phys., 5, 2497-2517, doi:10.5194/acp-52497-2005, 2005.

Bahreini, R., Middlebrook, A. M., Brock, C. A., de Gouw, J. A., McKeen, S. A., Williams, L. R., Daumit, K. E., Lambe, A. T., Massoli, P., Canagaratna, M. R., Ahmadov, R., Carrasquillo, A. J., Cross, E. S., Ervens, B., Holloway, J. S., Hunter, J. F., Onasch, T. B., Pollack, I. B., Roberts, J. M., Ryerson, T. B., Warneke, C., Davidovits, P., Worsnop, D. R., and Kroll, J. H.: Mass spectral analysis of organic aerosol formed downwind of the deepwater horizon oil spill: Field studies and laboratory confirmations, Environ. Sci. Technol., 46, 8025-8034, 2012. 
Cappa, C. D. and Wilson, K. R.: Multi-generation gas-phase oxidation, equilibrium partitioning, and the formation and evolution of secondary organic aerosol, Atmos. Chem. Phys., 12, 9505-9528, doi:10.5194/acp-12-9505-2012, 2012.

Chacon-Madrid, H. J. and Donahue, N. M.: Fragmentation vs. functionalization: chemical aging and organic aerosol formation, Atmos. Chem. Phys., 11, 10553-10563, doi:10.5194/acp11-10553-2011, 2011.

Chacon-Madrid, H. J., Murphy, B. N., Pandis, S. N., and Donahue, N. M.: Simulations of smog-chamber experiments using the twodimensional volatility basis set: Linear oxygenated precursors, Environ. Sci. Technol., 46, 11179-11186, 2012.

Chan, M. N., Chan, A. W. H., Chhabra, P. S., Surratt, J. D., and Seinfeld, J. H.: Modeling of secondary organic aerosol yields from laboratory chamber data, Atmos. Chem. Phys., 9, 5669-5680, doi:10.5194/acp-9-5669-2009, 2009.

Chen, S. and Brune, W. H.: Global sensitivity analysis of ozone production and $\mathrm{O}_{3}-\mathrm{NO}_{\mathrm{x}}-\mathrm{VOC}$ limitation based on field data, Atmos. Environ., 55, 288-296, 2012.

DeCarlo, P. F., Kimmel, J. R., Trimborn, A., Northway, M. J., Jayne, J. T., Aiken, A. C., Gonin, M., Fuhrer, K., Horvath, T., Docherty, K. S., Worsnop, D. R., and Jimenez, J. L.: Fielddeployable, High-resolution, Time-of-Flight Aerosol Mass Spectrometer, Anal. Chem., 78, 8281-8289, 2006.

Donahue, N. M., Robinson, A. L., Stanier, C. O., and Pandis, S. N.: Coupled partitioning, dilution, and chemical aging of semivolatile organics, Environ. Sci. Technol., 40, 2635-2643, 2006.

Donahue, N. M., Epstein, S. A., Pandis, S. N., and Robinson, A. L.: A two-dimensional volatility basis set: 1. organic-aerosol mixing thermodynamics, Atmos. Chem. Phys., 11, 3303-3318, doi:10.5194/acp-11-3303-2011, 2011.

Donahue, N. M., Henry, K. M., Mentel, T. F., Kiendler-Scharr, A., Spindler, C., Bohn, B., Brauers, T., Dorn, H. P., Fuchs, H., Tillmann, R., Wahner, A., Saathoff, H., Naumann, K.-H., Möhler, O., Leisner, T., Müller, L., Reinnig, M.-C., Hoffmann, T., Salo, K., Hallquist, M., Frosch, M., Bilde, M., Tritscher, T., Barmet, P., Praplan, A. P., DeCarlo, P. F., Dommen, J., Prévôt, A. S. H., and Baltensperger, U.: Aging of biogenic secondary organic aerosol via gas-phase $\mathrm{OH}$ radical reactions, P. Natl. Acad. Sci. USA, 109, 13503-13508, 2012a.

Donahue, N. M., Kroll, J. H., Pandis, S. N., and Robinson, A. L.: A two-dimensional volatility basis set - Part 2: Diagnostics of organic-aerosol evolution, Atmos. Chem. Phys., 12, 615-634, doi:10.5194/acp-12-615-2012, 2012b.

Drewnick, F., Hings, S. S., DeCarlo, P., Jayne, J. T., Gonin, M., Fuhrer, K., Weimer, S., Jimenez, J. L., Demerjian, K. L., Borrmann, S., and Worsnop, D. R.: A new Time-of-Flight Aerosol Mass Spectrometer (TOF-AMS) - Instrument description and first field deployment, Aerosol Sci. Technol., 39, 637-658, 2005.

Dzepina, K., Volkamer, R. M., Madronich, S., Tulet, P., Ulbrich, I. M., Zhang, Q., Cappa, C. D., Ziemann, P. J., and Jimenez, J. L.: Evaluation of recently-proposed secondary organic aerosol models for a case study in Mexico City, Atmos. Chem. Phys., 9, 5681-5709, doi:10.5194/acp-9-5681-2009, 2009.

El Haddad, I., D’Anna, B., Temime-Roussel, B., Nicolas, M., Boreave, A., Favez, O., Voisin, D., Sciare, J., George, C., Jaffrezo, J.-L., Wortham, H., and Marchand, N.: On the chemical nature of the oxygenated organic aerosol: implication in the for- mation and aging of $\alpha$-pinene SOA in a Mediterranean environment, Marseille, Atmos. Chem. Phys. Discuss., 12, 1976919797, doi:10.5194/acpd-12-19769-2012, 2012.

EPA: Our nation's air - Status and trends through 2010, US Environmental Protection Agency, Office of Air Quality Planning and Standards, Research Triangle Park, North Carolina, 2012.

Epstein, S. A., Riipinen, I., and Donahue, N. M.: A Semiempirical Correlation between Enthalpy of Vaporization and Saturation Concentration for Organic Aerosol, Environ. Sci. Technol., 44, 743-748, 2010.

Guenther, A., Hewitt, C. N., Erickson, D., Fall, R., Geron, C., Graedel, T., Harley, P., Klinger, L., Lerdau, M., McKay, W. A., Pierce, T., Scholes, B., Steinbrecher, R., Tallamraju, R., Taylor, J., and Zimmerman, P.: A global model of natural volatile organic compound emissions, J. Geophys. Res., 100, 8873-8892, 1995.

Hallquist, M., Wenger, J. C., Baltensperger, U., Rudich, Y., Simpson, D., Claeys, M., Dommen, J., Donahue, N. M., George, C., Goldstein, A. H., Hamilton, J. F., Herrmann, H., Hoffmann, T., Iinuma, Y., Jang, M., Jenkin, M. E., Jimenez, J. L., Kiendler-Scharr, A., Maenhaut, W., McFiggans, G., Mentel, Th. F., Monod, A., Prévôt, A. S. H., Seinfeld, J. H., Surratt, J. D., Szmigielski, R., and Wildt, J.: The formation, properties and impact of secondary organic aerosol: current and emerging issues, Atmos. Chem. Phys., 9, 5155-5236, doi:10.5194/acp-9-51552009, 2009.

Henry, K. M. and Donahue, N. M.: Effect of the OH radical scavenger hydrogen peroxide on secondary organic aerosol formation from $\alpha$-pinene ozonolysis, Aerosol Sci. Technol., 45, 696-700, 2011.

Henry, K. M., Lohaus, T., and Donahue, N. M.: Organic Aerosol Yields from $\alpha$-Pinene Oxidation: Bridging the Gap between First-Generation Yields and Aging Chemistry, Environ. Sci. Technol., 46, 12347-12354, 2012.

Jathar, S. H., Miracolo, M. A., Presto, A. A., Donahue, N. M., Adams, P. J., and Robinson, A. L.: Modeling the formation and properties of traditional and non-traditional secondary organic aerosol: problem formulation and application to aircraft exhaust, Atmos. Chem. Phys., 12, 9025-9040, doi:10.5194/acp-12-90252012, 2012.

Jimenez, J. L., Canagaratna, M. R., Donahue, N. M., Prevot, A. S. H., Zhang, Q., Kroll, J. H., DeCarlo, P. F., Allan, J. D., Coe, H., Ng, N. L., Aiken, A. C., Docherty, K. S., Ulbrich, I. M., Grieshop, A. P., Robinson, A. L., Duplissy, J., Smith, J. D., Wilson, K. R., Lanz, V. A., Hueglin, C., Sun, Y. L., Tian, J., Laaksonen, A., Raatikainen, T., Rautiainen, J., Vaattovaara, P., Ehn, M., Kulmala, M., Tomlinson, J. M., Collins, D. R., Cubison, M J., E., Dunlea, J., Huffman, J. A., Onasch, T. B., Alfarra, M. R., Williams, P. I., Bower, K., Kondo, Y., Schneider, J., Drewnick, F., Borrmann, S., Weimer, S., Demerjian, K., Salcedo, D., Cottrell, L., Griffin, R., Takami, A., Miyoshi, T., Hatakeyama, S., Shimono, A., Sun, J. Y., Zhang, Y. M., Dzepina, K., Kimmel, J. R., Sueper, D., Jayne, J. T., Herndon, S. C., Trimborn, A. M., Williams, L. R., Wood, E. C., Middlebrook, A. M., Kolb, C. E., Baltensperger, U., and Worsnop, D. R.: Evolution of organic aerosols in the atmosphere, Science, 326, 1525-1529, 2009.

Kang, E., Root, M. J., Toohey, D. W., and Brune, W. H.: Introducing the concept of Potential Aerosol Mass (PAM), Atmos. Chem. Phys., 7, 5727-5744, doi:10.5194/acp-7-5727-2007, 2007. 
Kroll, J. H., Chan, A. W. H., Ng, N. L., Flagan, R. C., and Seinfeld, J. H.: Reactions of Semivolatile Organics and Their Effects on Secondary Organic Aerosol Formation, Environ. Sci. Technol., 41, 3545-3550, 2007.

Kroll, J. H., Smith, J. D., Che, D. L., Kessler, S. H., Worsnop, D. R., and Wilson, K. R.: Measurement of fragmentation and functionalization pathways in the heterogeneous oxidation of oxidized organic aerosol, Phys. Chem. Chem. Phys., 11, 8005-8014, 2009.

Kroll, J. H., Donahue, N. M., Jimenez, J. L., Kessler, S. H., Canagaratna, M. R., Wilson, K. R., Altieri, K. E., Mazzoleni, L. R., Wozniak, A. S., Bluhm, H., Mysak, E. R., Smith, J. D., Kolb, C. E., and Worsnop, D. R.: Carbon oxidation state as a metric for describing the chemistry of atmospheric organic aerosol, Nat. Chem., 3, 133-139, 2011.

Lambe, A. T., Ahern, A. T., Williams, L. R., Slowik, J. G., Wong, J. P. S., Abbatt, J. P. D., Brune, W. H., Ng, N. L., Wright, J. P., Croasdale, D. R., Worsnop, D. R., Davidovits, P., and Onasch, T. B.: Characterization of aerosol photooxidation flow reactors: heterogeneous oxidation, secondary organic aerosol formation and cloud condensation nuclei activity measurements, Atmos. Meas. Tech., 4, 445-461, doi:10.5194/amt-4-445-2011, 2011.

Lambe, A. T., Onasch, T. B., Croasdale, D. R., Wright, J. P., Martin, A. T., Franklin, J. P., Massoli, P., Kroll, J. H., Canagaratna, M. R., Brune, W. H., Worsnop, D. R., and Davidovits, P.: Transitions from Functionalization to Fragmentation Reactions of Laboratory Secondary Organic Aerosol (SOA) Generated from the OH Oxidation of Alkane Precursors, Environ. Sci. Technol., 46, 5430-5437, 2012.

Lane, T. E., Donahue, N. M., and Pandis, S. N.: Simulating secondary organic aerosol formation using the volatility basis-set approach in a chemical transport model, Atmos. Environ., 42, 7439-7451, 2008.

Li, G., Rabitz, H., Yelvington, P. E., Oluwole, O. O., Bacon, F., Kolb, C. E., and Schoendorf, J.: Global sensitivity analysis for systems with independent and/or correlated inputs, J. Phys. Chem. A, 114, 6022-6032, 2010.

Mao, J., Ren, X., Brune, W. H., Olson, J. R., Crawford, J. H., Fried, A., Huey, L. G., Cohen, R. C., Heikes, B., Singh, H. B., Blake, D. R., Sachse, G. W., Diskin, G. S., Hall, S. R., and Shetter, R. E.: Airborne measurement of $\mathrm{OH}$ reactivity during INTEX-B, Atmos. Chem. Phys., 9, 163-173, doi:10.5194/acp-9-163-2009, 2009.

Massoli, P., Lambe, A. T., Ahern, A. T., Williams, L. R., Ehn, M., Mikkilä, J., Canagaratna, M. R., Brune, W. H., Onasch, T. B., Jayne, J. T., Petäjä, T., Kulmala, M., Laaksonen, A., Kolb, C. E., Davidovits, P., and Worsnop, D. R.: Relationship between aerosol oxidation level and hygroscopic properties of laboratory generated secondary organic aerosol (SOA) particles, Geophys. Res. Lett., 37, L24801, doi:10.1029/2010GL045258, 2010.

Murphy, B. N., Donahue, N. M., Fountoukis, C., and Pandis, S. N.: Simulating the oxygen content of ambient organic aerosol with the 2D volatility basis set, Atmos. Chem. Phys., 11, 7859-7873, doi:10.5194/acp-11-7859-2011, 2011.

Murphy, B. N., Donahue, N. M., Fountoukis, C., Dall'Osto, M., O'Dowd, C., Kiendler-Scharr, A., and Pandis, S. N.: Functionalization and fragmentation during ambient organic aerosol aging: application of the 2-D volatility basis set to field studies, Atmos. Chem. Phys., 12, 10797-10816, doi:10.5194/acp-1210797-2012, 2012a.
Murphy, B. N., Donahue, N. M., Fountoukis, C., Dall'Osto, M., O'Dowd, C., Kiendler-Scharr, A., and Pandis, S. N.: Functionalization and fragmentation during ambient organic aerosol aging: application of the 2-D volatility basis set to field studies, Atmos. Chem. Phys., 12, 10797-10816, doi:10.5194/acp-1210797-2012, 2012b.

Ng, N. L., Chhabra, P. S., Chan, A. W. H., Surratt, J. D., Kroll, J. H., Kwan, A. J., McCabe, D. C., Wennberg, P. O., Sorooshian, A., Murphy, S. M., Dalleska, N. F., Flagan, R. C., and Seinfeld, J. H.: Effect of $\mathrm{NO}_{\mathrm{x}}$ level on secondary organic aerosol (SOA) formation from the photooxidation of terpenes, Atmos. Chem. Phys., 7, 5159-5174, doi:10.5194/acp-7-5159-2007, 2007.

Ng, N. L., Canagaratna, M. R., Zhang, Q., Jimenez, J. L., Tian, J., Ulbrich, I. M., Kroll, J. H., Docherty, K. S., Chhabra, P. S., Bahreini, R., Murphy, S. M., Seinfeld, J. H., Hildebrandt, L., Donahue, N. M., DeCarlo, P. F., Lanz, V. A., Prévôt, A. S. H., Dinar, E., Rudich, Y., and Worsnop, D. R.: Organic aerosol components observed in Northern Hemispheric datasets from Aerosol Mass Spectrometry, Atmos. Chem. Phys., 10, 46254641, doi:10.5194/acp-10-4625-2010, 2010.

Odum, J. R., Hoffmann, T., Bowman, F., Collins, D., Flagan, R. C., and Seinfeld, J. H.: Gas/Particle partitioning and secondary organic aerosol yields, Environ. Sci. Technol., 30, 2580-2585, 1996.

Pankow, J. F.: An absorption model of the gas/aerosol partitioning involved in the formation of secondary organic aerosol, Atmos. Environ., 28, 189-193, 1994.

Pankow, J. F. and Asher, W. E.: SIMPOL.1: a simple group contribution method for predicting vapor pressures and enthalpies of vaporization of multifunctional organic compounds, Atmos. Chem. Phys., 8, 2773-2796, doi:10.5194/acp-8-27732008, 2008.

Pathak, R. K., Presto, A. A., Lane, T. E., Stanier, C. O., Donahue, N. M., and Pandis, S. N.: Ozonolysis of $\alpha$-pinene: parameterization of secondary organic aerosol mass fraction, Atmos. Chem. Phys., 7, 3811-3821, doi:10.5194/acp-7-3811-2007, 2007.

Perraud, V., Bruns, E. A., Ezell, M. J., Johnson, S. N., Yu, Y., Alexander, M. L., Zelenyuk, A., Imre, D., Chang, W. L., Dabdub, D., Pankow, J. F., and Finlayson-Pitts, B. J.: Nonequilibrium atmospheric secondary organic aerosol formation and growth, P. Natl. Acad. Sci. USA, 109, 2836-2841, doi:10.1073/pnas.1119909109, 2012.

Presto, A. A., Huff Hartz, K. E., and Donahue, N. M.: Secondary organic aerosol production from terpene ozonolysis. 1. Effect of UV radiation, Environ. Sci. Technol., 39, 7036-7045, 2005.

Robinson, A. L., Donahue, N. M., Shrivastava, M. K., Weitkamp, E. A., Sage, A. M., Grieshop, A. P., Lane, T. E., Pierce, J. R., and Pandis, S. N.: Rethinking organic aerosols: semivolatile emissions and photochemical aging, Science, 315, 1259-1262, 2007.

Roldin, P., Swietlicki, E., Schurgers, G., Arneth, A., Lehtinen, K. E. J., Boy, M., and Kulmala, M.: Development and evaluation of the aerosol dynamics and gas phase chemistry model ADCHEM, Atmos. Chem. Phys., 11, 5867-5896, doi:10.5194/acp-11-58672011, 2011.

Saltelli, A., Ratto, M., Andres, T., Campolongo, F., Cariboni, J., Gatelli, D., Saisana, M., and Tarantola, S.: Global Sensitivity Analysis, The Primer, John Wiley \& Sons, Ltd., 2008.

Sander, S. P., Abbatt, J., Barker, J. R., Burkholder, J. B., Friedl, R. R., Golden, D. M., Huie, R. E., Kolb, C. E., Kurylo, M. J., 
Moortgat, G. K., Orkin, V. L., and Wine, P. H.: Chemical Kinetics and Photochemical Data for Use in Atmospheric Studies, Evaluation No. 17, JPL Publication 10-6, Jet Propulsion Laboratory, Pasadena, 2011, http://jpldataeval.jpl.nasa.gov, 2011.

Saukko, E., Lambe, A. T., Massoli, P., Koop, T., Wright, J. P., Croasdale, D. R., Pedernera, D. A., Onasch, T. B., Laaksonen, A., Davidovits, P., Worsnop, D. R., and Virtanen, A.: Humiditydependent phase state of SOA particles from biogenic and anthropogenic precursors, Atmos. Chem. Phys., 12, 7517-7529, doi:10.5194/acp-12-7517-2012, 2012.

Shiraiwa, M. and Seinfeld, J. H.: Equilibration timescale of atmospheric secondary organic aerosol partitioning, Geophys. Res. Lett., 39, L24801, doi:10.1029/2012GL054008, 2012.

Shrivastava, M., Fast, J., Easter, R., Gustafson Jr., W. I., Zaveri, R. A., Jimenez, J. L., Saide, P., and Hodzic, A.: Modeling organic aerosols in a megacity: comparison of simple and complex representations of the volatility basis set approach, Atmos. Chem. Phys., 11, 6639-6662, doi:10.5194/acp-11-6639-2011, 2011.

Spracklen, D. V., Jimenez, J. L., Carslaw, K. S., Worsnop, D. R., Evans, M. J., Mann, G. W., Zhang, Q., Canagaratna, M. R., Allan, J., Coe, H., McFiggans, G., Rap, A., and Forster, P.: Aerosol mass spectrometer constraint on the global secondary organic aerosol budget, Atmos. Chem. Phys., 11, 12109-12136, doi:10.5194/acp-11-12109-2011, 2011.
Stanier, C. O., Donahue, N., and Pandis, S. N.: Parameterization of secondary organic aerosol mass fractions from smog chamber data, Atmos. Environ., 42, 2276-2299, 2008.

Virtanen, A., Joutsensaari, J., Koop, T., Kannosto, J., Yli-Pirila, P., Leskinen, J., Makela, J. M., Holopainen, J. K., Pöschl, U., Kulmala, M., Worsnop, D. R., and Laaksonen, A.: An amorphous solid state of biogenic secondary organic aerosol particles, Nature, 467, 824-827, 2010.

Wagstrom, K. M. and Pandis, S. N.: Determination of the age distribution of primary and secondary aerosol species using a chemical transport model, J. Geophys. Res., 114, D14303, doi:14310.11029/12009JD011784, 2009.

Yu, S., Bhave, P. V., Dennis, R. L., and Mathur, R.: Seasonal and regional variations of primary and secondary organic aerosols over the continental United States: semi-empirical estimates and model evaluation, Environ. Sci. Technol., 41, 4690-4697, 2007. 